NASA/CR- /997 207774

neprinted from

$N-6 \cdots$

(c)
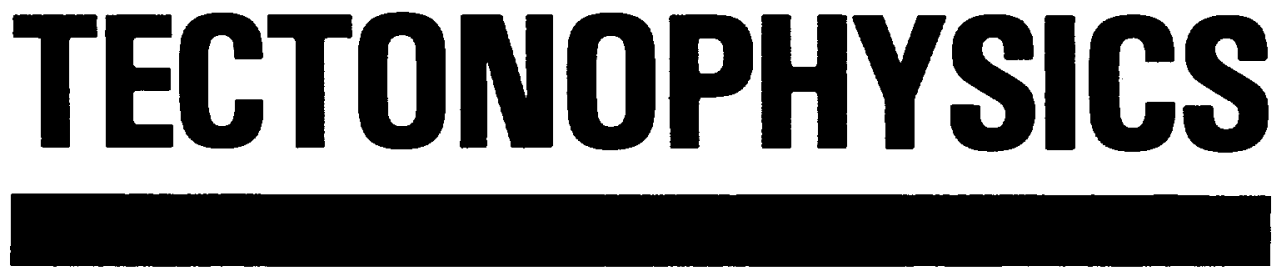

INTERNATIONAL JOURNAL OF GEOTECTONICS AND THE GEOLOGY AND PHYSICS OF THE INTERIOR OF THE EARTH

Breccia formation at a complex impact crater: Slate Islands, Lake Superior, Ontario, Canada

B.O. Dressler *, V.L. Sharpton

Lunar and Planetary Institute. 3600 Bay Area Boulevard. Houston. TX 77058-1113. USA

Received 21 May 1996; accepted 6 January 1997

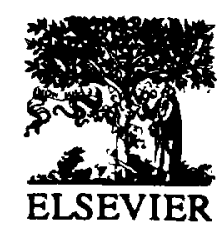




\section{TECTONOPHYSICS}

\section{Editors-in-Chief}

J.P BRUN

T. ENGELDER

K.P. FURLONG

F. WENZEL

Honorary Editors:

Université de Rennes, Institut de Géologie, Campus de Beaulieu, Ave. du Général Leclerc, Rennes 35042 Cedex France. Phone: +33.99.28 61 23; FAX: +33.99.2867 80; e-mait: dirgeosc@univ-rennest.fr

Pennsylvania State University, College of Earth \& Mineral Sciences, 336 Deike Building. University Park, PA 16802, USA Phone: +1.814.865.3620/466.7208; FAX: +1.814.863.7823; e-mail: engelder@geosc.psu.edu

Pennsylvania State University, Department of Geosciences, 439 Deike Building, University Park, PA 16802, USA. Phone: +1.814 .863 .0567 ; FAX: +1.814.865.3191; e-mail: kevin @ geodyn.psu.edu

Universität Fridericiana Karlsruhe, Geophysikalisches Institut, Hertzstraße 16, Bau 42, D-76187 Karlsruhe, Germany. Phone +49.721.608 4431; FAX: +49.721.711173; e-mail: fwenzel@gpiwap1.physik.uni-karlsruhe.de

\section{Friedman}

S. Uyeda

\section{Editorial Board}

D.L. Anderson, Pasadena, CA

H.G. Avé Lallemant, Houston, TX

E. Banda, Barcelona

Z. Ben-Avraham, Tel Aviv

$H$. Berckhemer, Koenigstein

C. Blot, Sollies-Pont

G.C. Bond, Palisades, NY

G.J. Borradaile, Thunder Bay, Ont.

B.C. Burchtiel, Cambridge, MA

K.C. Burke, Houston, TX

S. Cloetingh, Amsterdam

P.R. Cobbold, Rennes

D. Denham, Canberra, ACT

J.F. Dewey, Oxford

G.H. Eisbacher, Karlsruhe

E.R. Engdahl, Denver, CO

E.R. Flüh, Kiel

K. Fujita, East Lansing, Ml

Y. Fukao, Tokyo

R. Geller, Tokyo

J.P. Gratier, Grenoble

A.G. Green, Zürich

R.H. Groshong. Jr., Tuscaloosa, AL

H.K. Gupta, Hyderabad

T.W.C. Hilde, College Station, TX

A. Hirn, Paris

F. Horváth, Budapest

E.S. Husebye, Bergen

H. Kanamori, Pasadena, CA

S. Karato, Minneapolis, MN

R.J. Knipe, Leeds

M. Kono, Tokyo

$X$. Le Pichon, Paris

G.S. Lister, Clayton, Vic.

R.I. Madariaga, Paris

Y. Mart, Haifa

M. McNutt, Cambridge, MA

W.D. Means, Albany, NY

K. Mengel, Clausthal-Zellerfeld

A. Nicolas, Montpellier

G. Oentel, Los Angeles, CA

A. Pérez-Estaun, Oviedo

H.N. Pollack, Ann Arbor, MI

C.McA. Powell, Nedlands, W.A.

L. Ratschbacher, Würzburg

E.H. Rutter, Manchester

M.P. Ryan, Reston, VA

D.J. Sanderson, Southampton
S.M. Schmid, Basel

W.M. Schwerdtner, Toronto, Ont.

C. Şengör, Istanbul

T. Seno, Tokyo

Shi Yang-Shen, Nanjing

N. Sleep, Stanford, CA

S. Sobolev, Karlsruhe

C.A. Stein, Chicago, IL

$P$ Suhadolc, Trieste

K. Tamaki, Tokyo

M. Torné, Barcelona

C.I. Trifu, Kingston, Ont.

J. Tullis, Providence, RI

D.L. Turcotte, Ithaca, NY

B.A. van der Pluiim, Ann Arbor, MI

R. van der Voo, Ann Arbor, Ml

B.C. Vendeville, Austin, TX

R.L.M. Vissers, Utrecht

J.S. Watkins, College Station, TX

H.-R. Wenk, Berkeley, CA

G. Westbrook, Birmingham

B.F. Windley, Leicester

M.J.R Wortel, Utrecht

P.A. Ziegler, Binningen

Scope of the journal

Tectonophysics is an international medium for the publication of original studies and comprehensive reviews in the field of geotectonics and the geology and physics of the earth's crust and interior. The editors will endeavour to maintain a high scientific level and it is hoped that with its international coverage the journal will contribute to the sound development of this field.

(Text continued on inside back cover)

(C) 1997, ELSEVIER SCIENCE B.V. ALL RIGHTS RESERVED.

$0040-1951 / 97 / \$ 17.00$

This journal and the individual contributions contained in it are protected by the copyright of Elsevier Science B.V., and the following terms and conditions apply to their use:

Photocopying: Single photocopies of single articles may be made tor personal use as allowed by national copyright faws. Permission of the publisher and payment of a fee is required for all other photocopying, including multiple or systematic copying, copying for advertising or promotional purposes, resale, and all forms of document delivery. Special rates are available for educational institutions that wish to make photocopies for non-profit educational classroom use.

In the USA, users may clear permissions and make payment through the Copyright Clearance Center, Inc., 222 Rosewood Drive, Danvers, MA 01923, USA. In the UK, users may clear permissions and make payments through the Copyright Licensing Agency Rapid Clearance Service (CLARCS), 90 Totenham Coun Road, London W1P OLP, UK. In other countries where a local copyright clearance center exists, please contact it for information on required permisssions and payments.

Derivative Works: Subscribers may reproduce tables of contents or prepare lists of articles including abstracts for internal circulation within their institutions. Permission of the Publisher is required for resale or distribution outside the institution.

Permission of the Publisher is required for all other derivative works, including compilations and translations.

Electronic Storage: Permission of the Publisher is required to store electronically any material contained in this journal, including any article or part of an article. Contact the Publisher at the address indicated.

Except as outlined above, no part of this publication may be reproduced, stored in a retrieval system or transmitted in any form or by any means, electronic, mechanical, photocopying, recording or otherwise, without written permission of the Publisher.

Notice: No responsibility is assumed by the Publisher for any injury and/or damage to persons or property as a matter of products liability, negligence or otherwise, or from any use or operation of any methods, products, instructions or ideas contained in the material herein 
TECTONOPHYSICS

Tectonophysics 275 (1997) 285-311

\title{
Breccia formation at a complex impact crater: Slate Islands, Lake Superior, Ontario, Canada
}

\author{
B.O. Dressler*, V.L. Sharpton \\ Lunar and Planetary Institute, 3600 Bay Area Boulevard, Houston, TX 77058-1113, USA
}

Received 21 May 1996; accepted 6 January 1997

\begin{abstract}
The Slate Islands impact structure is the eroded remnant of a $\sim 30-32 \mathrm{~km}$-diameter complex impact structure located in northern Lake Superior, Ontario, Canada. Target rocks are Archean supracrustal and igneous rocks and Proterozoic metavolcanics, metasediments, and diabase. A wide variety of breccias occurs on the islands, many of which contain fragments exhibiting shock metamorphic features. Aphanitic, narrow and inclusion-poor pseudotachylite veins, commonly with more or less parallel boundaries and apophyses branching off them, represent the earliest breccias formed during the compression stage of the impact process. Coarse-grained, polymictic clastic matrix breccias form small to very large. inclusion-rich dikes and irregularly shaped bodies that may contain altered glass fragments. These breccias have sharp contacts with their host rocks and include a wide range of fragment types some of which were transported over minimum distances of $\sim 2 \mathrm{~km}$ away from the center of the structure. They cut across pseudotachylite veins and contain inclusions of them. Field and petrographic evidence indicate that these polymictic breccias formed predominantly during the excavation and central uplift stages of the impact process. Monomictic breccias, characterized by angular fragments and transitional contacts with their host rocks, occur in parautochthonous target rocks, mainly on the outlying islands of the Slate Islands archipelago. A few contain fragmented and disrupted, coarse-grained, polymictic clastic matrix breccia dikes. This is an indication that at least some of these monomictic breccias formed late in the impact process and that they are probably related to a late crater modification stage. A small number of relatively large occurrences of glass-poor, suevitic breccias occur at the flanks of the central uplift and along the inner flank of the outer ring of the Slate Islands complex crater. A coarse, glass-free, allogenic breccia, containing shatter-coned fragments derived from Proterozoic target rocks (upper target strata), observed at two locations may be analogous to the 'Bunte Breccia' of the Ries crater in Germany. At one of these locations, this breccia lies close to a crater suevite deposit. At the other, it overlies parautochthonous, monomictic breccia. The Slate Islands impact breccias are superbly exposed, much better than breccias in most other terrestrial impact structures. Observations, including those indicative of multiple and sequential processes, provide insight on how impact breccias form and how they relate to the various phases of the impact process. Eventually they will lead to an improved understanding of planetary impact processes.
\end{abstract}

Keywords: impact crater; Slate Islands; breccia; pseudotachylite

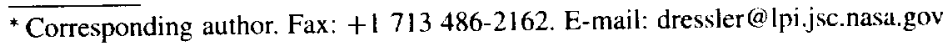

0040-1951/97/\$17.00@1997 Elsevier Science B.V. All rights reserved.

PII S0040-1951(97)00003-6 


\section{Introduction}

The Slate Islands impact structure is located in northern Lake Superior, $\sim 10 \mathrm{~km}$ south of Terrace Bay, Ontario, Canada (Fig. 1). Various types of breccias, shatter cones, and rocks with microscopic shock metamorphic features are present on the islands and provide convincing evidence that the structure was formed as the result of comet or asteroid impact (e.g. Halls and Grieve, 1976; Grieve and Robertson, 1976; Grieve et al., 1995; cf. Sage, 1978, 1991).

A large portion of the island group comprising two large and several small islands appears to represent the partially eroded central uplift of a complex impact crater. Bathymetric information obtained from around the islands group roughly outlines the shape of a complex impact crater, originally $\sim 30-32$ $\mathrm{km}$ in diameter (Halls and Grieve, 1976; Dressler et al., 1995; Sharpton and Dressler, 1996; Sharpton et al., 1996a). The structure has been selected for an in-depth investigation of the various rock units and target rock deformations related to impact. Erosion on the islands and large, wave-battered shore exposures provide excellent two- and three-dimensional views of lithological and structural elements of the central uplift of a complex impact structure. We know of no terrestrial impact structure of comparable size with equal or better exposures of rocks of the central part of the structure.

A wide variety of breccia types are known to occur at terrestrial impact structures and they have been described in considerable detail. Hüttner (1969) and Engelhardt and Graup (1984), for example, reported on breccias of the Ries impact structure in Germany, whereas Dressler (1984) and Muir and Peredery (1984) described breccias of the Sudbury structure in Ontario. Lambert (1981), Bischoff and Oskierski (1987), Stöffler et al. (1988), Redeker and Stöffler (1988), Martini (1991), Reimold (1995) and Sharpton et al. (1996b), and references therein, to list only a few more relevant publications, worked on a number of other terrestrial impact structures or, in more general terms, dealt with impact-triggered rock brecciation. Despite this impressive research, impact breccia formation, in our opinion, is not adequately understood, especially as it relates to the formation of various types of breccia in autochthonous and parautochthonous target rocks of the crater floor and the central uplift. With this in mind, we have studied a large number of breccia occurrences at Slate Islands (Fig. 1) and collected a considerable number of samples for laboratory investigation. Here, we present the results of this study and relate the observed breccia types to the various stages of the impact process as presently understood, namely the compression, excavation and central uplift and crater modification phases. We are, however, aware that the customary step-by-step depiction of the impact process is a convenient simplification only. Our approach and some of our results are similar to those of Lambert (1981) and Bischoff and Oskierski (1987), who also attempted to relate various breccia types to specific impact phases.

\section{General geology and age of the Slate Islands structure}

A considerable variety of Archean and Proterozoic rocks underlie the Slate Islands archipelago (Sage, 1991; Fig. 1). Archean lithologies make up the bulk of the bedrock and belong to the Wawa Subprovince of the Superior Province of the Canadian Shield. They are $\sim 2.7 \mathrm{Ga}$ old (Ontario Geological Survey, 1992) and consist of felsic to mafic pyroclastic rocks, variolitic and pillowed basalt flows, and feldspar porphyry flows. These supracrustal rocks range in composition from calc-alkalic dacite to tholeiitic basalt and are interbedded with ironstones, mudstones and siltstones. The clastic metasedimentary rocks are derived from volcanic rocks. Conglomerates, containing volcanic and chert clasts, also occur, but are not common. Quartz-feldspar porphyries and gabbros, also Archean in age, intrude the supracrustal rocks. All Archean rocks have been regionally metamorphosed to greenschist facies rank (Sage, 1991).

Proterozoic rocks are of limited spatial extent (Sage, 1991). Among them are laminated argillite and chert-carbonate-hematite ironstone of the Gunflint Formation and possibly siltstone of the Rove Formation, all of the 1.8 to $1.9 \mathrm{Ga}$ Animikie Group. Mafic metavolcanic rocks and interflow quartz sandstone and siltstone, and diabase dikes of the $\sim 1.1 \mathrm{Ga}$ old Osler Group, Keweenawan Supergroup, also occur (Sage, 1991). On the basis of the seismic profiles of the Great Lakes International Multidisciplinary 


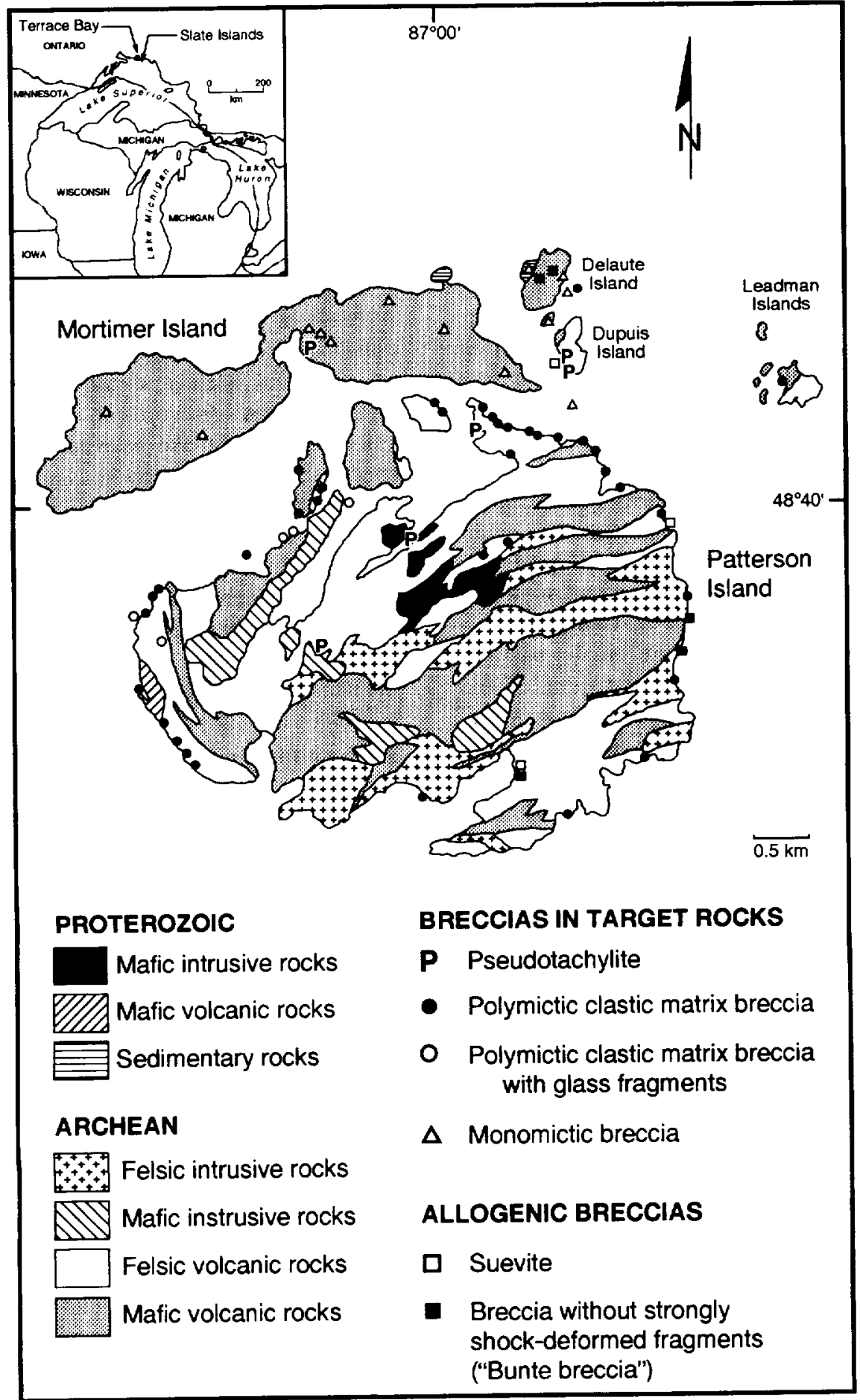

Fig. 1. General geology and location of Slate Islands impact structure (after Sage, 1991). Also shown are the locations of the various breccia types observed on the islands. 
Program on Crustal Evolution (GLIMPCE) (Mariano and Hinze, 1994) and the reprocessed northern part of GLIMPCE Line A (courtesy of B. Milkereit, Geological Survey of Canada, 1994; Sharpton and Dressler, 1996) the Keweenawan units are believed by us to represent an originally $>5 \mathrm{~km}$ thick sequence of weakly southward dipping, seismically strongly reflective units that made up the upper target stratigraphy at the time of the Slate Islands impact event. The Keweenawan rocks were probably overlain by sandstone of the Jacobsville Formation. Sandstone fragments, interpreted by us as derived from units of this formation, occur in the impact breccias. Several lamprophyre dikes have been observed by Sage (1991) along the southeast coast of Patterson Island (not shown on Fig. 1).

All the above Archean and Proterozoic target rocks have been noted by us as fragments in impact breccias exposed on the islands. Considering this observation alone, the structure has a minimum age of $1.1 \mathrm{Ga}$. Grieve et al. (1995) suggested an age of $\sim 350 \mathrm{Ma}$ for the structure on the basis of the similarity of its erosional level to that of the Charlevoix structure in Quebec. This impact structure has been radiometrically dated at $357 \pm 15 \mathrm{Ma}$ (Rondot, 1971; Grieve et al., 1995). However, Grieve et al. (1995) realized that erosion levels can vary considerably, especially in areas that were subject to glaciation. Therefore, their estimate can be taken only as a very rough approximation. Sage (1991) presented $\mathrm{K}$-Ar ages of $282 \pm 11$ Ma for phlogopite and $310 \pm 18 \mathrm{Ma}$ for antigorite of a lamprophyre dike that had been subjected to impact brecciation. More recently, however, the same lamprophyre was radiometrically dated at a Keweenawan age of 1.1 $\mathrm{Ga}$ by the more reliable $\mathrm{U}-\mathrm{Pb}$ method on perovskite (L. Heaman, University of Alberta, Edmonton, pers. commun., 1994). As stated above, we have observed breccias on the islands containing sandstone and siltstone fragments that resemble units of the Jacobsville Formation. This suggests a maximum age of about $800 \mathrm{Ma}$ for the Slate Islands impact structure based on assignment of the Jacobsville Formation as Hadrynian (Card et al., 1994). The Slate Islands lie between the Phanerozoic Michigan and Hudson Bay Lowlands basins. The region between these two basins very probably was underlain by Ordovician to Devonian sedimentary rocks (Norris and Sanford,
1968). However, we did not notice any fragments of these Phanerozoic rocks in the Slate Islands impact breccias. This may indicate an absence of these rocks at the time of impact and an age of $>350 \mathrm{Ma}$ for the structure. These observations lead us to conclude that the structure is between $\sim 350$ and $800 \mathrm{Ma}$ old. Radiometric age determinations on pseudotachylite and on rocks interpreted as impact melts and collected during the 1995 field season are under way and hopefully will better constrain the age of this structure.

More or less all bedrock on the islands is brecciated to various degrees. On Patterson Island and other central islands of the archipelago, there is hardly a shore outcrop not exhibiting some breccia body (Fig. 1). We have also observed breccias in the interior of Patterson Island and most other islands. However, on the islands themselves, away from the shores, breccias are not well exposed because of dense vegetation and erosion: breccias are in general less resistant to erosion than bedrock. A search for breccias, microscopic shock metamorphic features, and shatter cones in the Archean rocks on the mainland north of Slate Islands was negative.

\section{The impact process}

Approximately 150 terrestrial impact structures are presently known (Grieve et al., 1995) and over the last 30 years meteorite impact has become an accepted geological process within the geoscience community. Three types of impact structures occur on earth and have also been observed on the planets of the solar system: 'Simple craters', 'complex craters', and 'multi-ring basins'. Simple craters are bowl-shaped and, on earth, have rim diameters of up to about $2 \mathrm{~km}$ in sedimentary target rocks, and up to $4 \mathrm{~km}$ in crystalline targets (Dence, 1972). The rim area of simple craters is locally upturned, such as at the Barringer (= Meteor) crater in Arizona. This 50,000 year old and $1.2 \mathrm{~km}$-diameter crater is perhaps the best studied simple crater on earth.

Complex craters are larger than simple craters and have a central uplifted area, either a central peak or a peak ring surrounded by an annular trough or depression. These craters are filled in part by allogenic breccias derived from the target rocks and/or by impact melt rocks. Amongst the best known terrestrial complex craters are the Ries crater in Germany 
(Preuss and Schmidt-Kaler, 1969; Engelhardt, 1990 and references therein), the Manicouagan structure (Murtaugh, 1975, 1976; Dressler, 1970, 1990; Floran et al., 1978), and the Puchezh-Katunki, Popigai, and Kara structures in Russia (Masaitis et al., 1994). Fig. 2 describes, in a simplified form, the formation of a complex impact structure, such as the Slate Islands structure. This figure illustrates that the collapse and modification of the transient crater involve an area considerably larger than occupied by the transient cavity alone resulting in structural deformation surrounding the central uplift.

The largest impact structures are multi-ring basins. They are characterized by several structural rings surrounding a topographic crater form. In their pristine shape they are best known from the earth's moon (Spudis, 1993 and references therein). On
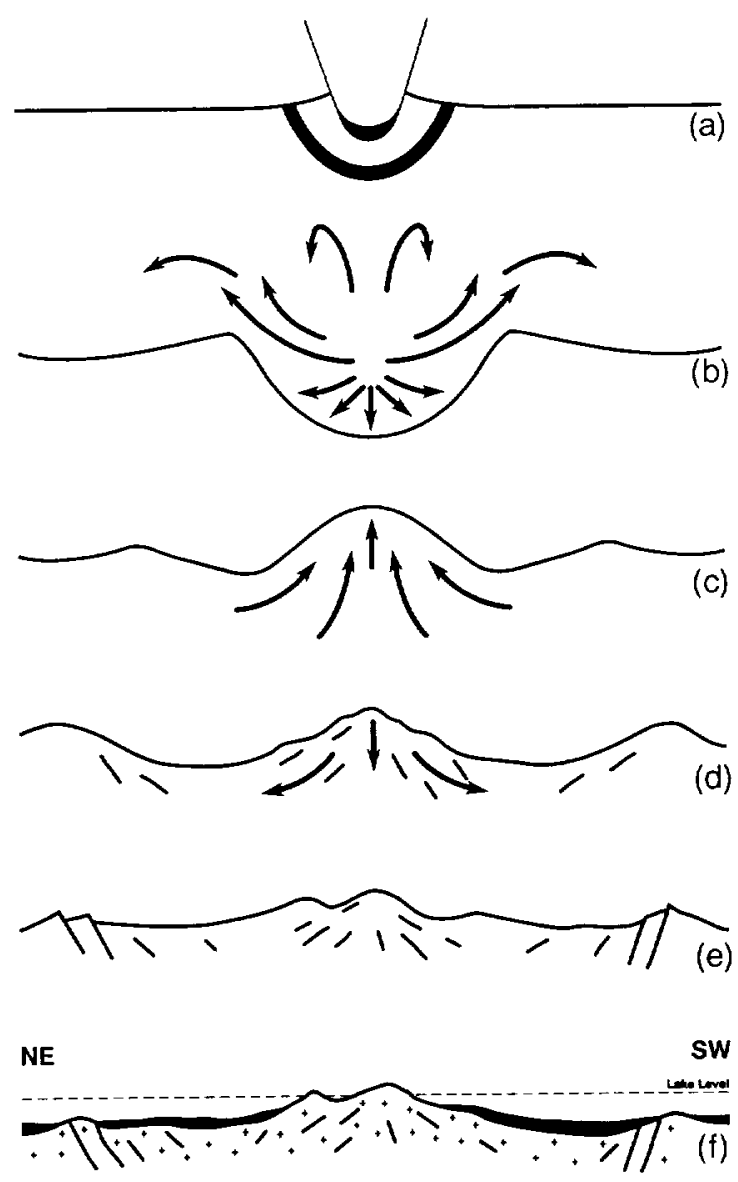

earth, three large multi-ring basins have been recognized. One of them is the 65-Ma-old Chicxulub structure in Yucatan, Mexico, of $180-300 \mathrm{~km}$ diameter (Sharpton et al., 1993), which is completely covered by younger sedimentary rocks. Its multi-ring character is derived from gravity analysis (Sharpton et al., 1993). The other two multi-ring basin structures are both strongly eroded. They are the Vredefort structure in South Africa (2024 \pm 3 Ma, Kamo et al., 1995; $\sim 250 \mathrm{~km}$ diameter, Therriault et al., 1993. 1995; Henkel and Reimold, 1966; S. Kamo, pers. commun., 1966) and the deformed Sudbury structure in Ontario, Canada $(1.85 \mathrm{Ga} ;>190 \mathrm{~km}$ in diameter; Peredery and Morrison, 1984; Dressler et al., 1987; Grieve et al., 1991; Deutsch et al., 1995). On the basis of their large size, they are believed to represent multi-ring basins.

Upon impact, a portion of the kinetic energy of an impacting asteroid or comet is partitioned into kinetic energy in the target rock and is transferred by a supersonic shock wave. This compressional shock sets target rocks into hemispherically downward and outward motion while rocks near the target

Fig. 2. Formation of the Slate Islands complex impact structure (a) Impact and evaporation of projectile - growing transient crater lined with impact melt. Shock wave expands hemispherically downward and outward at a faster rate than the growth of the crater. (b) Compression and excavation - growth of transient crater. Figure shows shape of transient crater. Note that the transient crater has a considerably smaller diameter than the final structure (e, below). Deposition of ejected material and its deposition as allogenic breccias is continuing during central uplift phase (not shown in profile (c). (c) Central uplift. Note that flow of material is upwards not only from directly beneath ground zero but also from more peripheral locations. Driving forces are rebound of shock compressed rocks and gravitational collapse of unstable transient crater. Note that rocks from deepest level of transient crater form the peak of the central uplift. Faulting during the central uplift and central uplift collapse phases, however, may allow substantial movement of parts of the central uplift against each other. This can result in direct juxtaposition of strongly shock-deformed rocks with relatively little shock-metamorphosed rocks in the central uplift. (d) Gravity-driven collapse of central uplift and crater modification resulting in a relatively flat profile compared with the shape of the transient crater. (e) Final form of impact structure. Note peripheral faults and terraces. (f) Present shape of Slate Islands impact structure after partial crosion (black: allogenic breccias and impact melt. assumed). Profile is based on bathymetric information from around the archipelago and on topographic maps of the island group. 
surface are ejected from the growing crater cavity, all this leading to the formation of a 'transient crater' (Fig. 2). This transient cavity is unstable, resulting, in case of larger, complex craters, in rebound of the central crater basement and inward collapse of the crater walls. All these impact stages, as well as the following partial or complete collapse of the central uplift and the late-stage crater modification, produce breccias in the impact structure region. In most terrestrial impact craters, these breccias are relatively poorly exposed due to erosion, vegetation cover, or post-impact sedimentation. At Slate Islands, however, we have an opportunity to study spectacular outcrops of impact breccias in the central portion of a complex crater, characterized by a very heterogeneous target rock assembly.

Rock brecciation and shatter-coning are macroscopic characteristics of impact structures. Amongst microscopic shock metamorphic features are fracturing, kink banding (neither in themselves diagnostic of shock deformation) and melting. Planar microdeformation features, deformation bands, and solid-state mineral transformation are indicative of high shock pressures and, consequently, of impact. Solid-state transformations result in the formation of high-pressure mineral phases such as coesite and stishovite (Stöffler, 1971a) and solid-state diaplectic glass. Very high pressures result in rock melting (and rock vaporization) and rapid temperature excursions that generate glasses of both whole-rock and constituent mineral composition. The properties of all these shock features and their genetic significance have been described by a considerable number of researchers, e.g. in French and Short (1968), Engelhardt and Bertsch (1969), Stöffler (1971a,b, 1974, 1984), Stöffler and Langenhorst (1994), and Grieve et al. (1996).

At the Slate Islands structure, microscopic planar deformation features in quartz and feldspar have been observed by Halls and Grieve (1976), Sage (1991), and by Dressler et al. (1994). Grieve and Robertson (1976) studied the spatial variation of shock deformation on the islands. Preliminary results on an expansion of this effort were published by Dressler et al. (1995). The shock features are seen in target rocks and in breccia components. Impact glasses and melt rocks have also been observed (Dressler et al., 1994, 1995).
In nature, the actual formation of microscopic shock features, impact breccias, glasses, and melts has not been witnessed. Asteroid and comet impacts occur very rapidly, compared with practically all common geological processes. Direct observation of large body impact is not possible. Small impact experiments and the investigation of chemical and nuclear explosion tests, however, provide some valuable insight into various aspects and stages of the impact process. Planetary impact, however, is considerably more complex than these small-scale analogues. In addition to experiments and model calculations, we, therefore, depend on field studies and laboratory research to advance our understanding of planetary impact processes, including an understanding of impact-related rock brecciation.

In the following we describe the various breccia types found at the Slate Islands impact structure. We are able to demonstrate that not all breccias at the structure formed simultaneously, that there is a sequential order to breccia formation, and that it is possible to assign specific breccia types to the various stages of the impact process. Attempts to this effect have been made at other impact structures, for example by Lambert (1981), Bischoff and Oskierski (1987), and Stöffler et al. (1988).

\section{Petrology of Slate Islands impact breccias}

Several types of breccias similar to those described from other terrestrial impact structures have been observed at the Slate Islands structure: (1) pseudotachylite ${ }^{1}$ veins and small dikes similar to pseudotachylites at the Vredefort structure in South Africa (Shand, 1916; Martini, 1991; Reimold, 1995; Reimold and Colliston, 1994 and references therein), the Sudbury structure in Ontario, Canada (Fairbairn and Robson, 1942; Speers, 1957; Dressler, 1984; Müller-Mohr, 1992; Thompson and Spray, 1994; Spray and Thompson, 1995 and references therein), the Manicouagan structure, Quebec, Canada (Dressler, 1970, 1990; Murtaugh, 1975, 1976), and other impact structures (Reimold, 1995); (2)

\footnotetext{
'Pseudotachylite' is used here as a strictly descriptive term for tachylite-like, dark grey or black, aphanitic inclusion-bearing veins and irregularly shaped bodies that may have glassy, fine-grained, igneous or clastic matrices.
} 
polymictic clastic matrix breccias like those at the Rochechouart structure in France (Bischoff and Oskierski, 1987), the Ries structure in Germany (Stöffler, 1977; Stöffler et al., 1988) and the Charlevoix structure in Quebec (Rondot, 1995), to name just a few; (3) monomictic, parautochthonous breccias are similar to those observed, for example, at the Manicouagan structure (Dressler, 1970; Murtaugh, 1975, 1976) and several other Canadian structures (Dence, 1968). Allogenic, fallback breccias are not very common at Slate Islands. However, they probably form extensive deposits around the island group beneath the waters of Lake Superior.

\subsection{Breccias in the target rocks}

The Slate Islands are believed to represent the central uplift (Halls and Grieve, 1976) and part of an annular ring of a complex impact crater (Sharpton and Dressler, 1996). The complex and heterogeneous target rocks are characterized by strong brecciation. The degree to which the various target rocks are brecciated varies considerably from one place to the other within the island group, but we estimate that, in total, breccias make up $\sim 15$ to $25 \%$ of the rocks that underlie the islands.

\subsubsection{Pseudotachylites}

The term 'pseudotachylite' was introduced by Shand (1916) to describe veins, dikes ${ }^{2}$ and irregularly shaped bodies of dark-colored, fine-grained, inclusion-bearing rocks in the Vredefort structure of South Africa. Pseudotachylites are formed as the result of brittle or brittle-ductile seismic faulting and also have been described from a number of terrestrial impact structures (Reimold, 1995 and references therein). In tectonic regimes, they are thought to form by friction melting (e.g. Sibson, 1975; Magloughlin and Spray, 1992; Swanson, 1992; Spray, 1995) or by strong cataclasis (Wenk, 1978). In impact structures, they could have been generated by friction melting and/or shock brecciation and/or impact melting. In both the tectonic and impact regimes, the generation of pseudotachylite is

\footnotetext{
${ }^{2}$ The term 'dike' (a tabular body) is used in this publication in a descriptive, not a genetic sense. It does not necessarily denote an intrusive origin.
}

a very rapid and dynamic process, probably ranging from the microsecond to the one-to-two-second range.

The discussion on the origin of pseudotachylite is as old as the term itself. In the more recent literature (Reimold, 1995 and references therein) pseudotachylites are described as formed by friction melting. At the Vredefort structure, Martini (1991) distinguished between two types of pseudotachylite. The first type commonly forms thin dikelets and is characterized by dark gray, aphanitic material, which has fluidal melt textures and sharp contacts with host rocks. The second, according to him, forms large bodies and long dikes, is filled with dark very finegrained clastic material, which supports a wide range of rock fragments of various sizes and shapes. This was criticized by Reimold et al. (1992) and Reimold (1995) who believe that the first pseudotachylite type of Martini (1991) refers to impact melt and not friction melt. Sudbury Breccias, i.e. 'pseudotachylites', very similar in appearance to those at the Vredefort structure, occur at the Sudbury structure, where they have been described as having melt and clastic matrices (Dressler, 1984; Peredery and Morrison. 1984). Pseudotachylites in impact structures, therefore, may very well form through friction melting, impact melting, explosive cataclasis and/or a combination of these processes. In this publication, we use the term pseudotachylite in reference to Slate Islands breccias that are texturally and dimensionally similar to pseudotachylites of other impact structures, as described below, regardless of the specific mode of formation.

We have noted pseudotachylite bodies in a few places in the archipelago only (Fig. 1). However, the relatively small veins and dikes are not very conspicuous and may not be that uncommon. Thin dikelets and anastomosing veinlets contain few or no fragments larger than a few millimeters in size, wider ones may or may not contain a more substantial volume of fragments derived from the host rock. Their black or dark gray, aphanitic matrix has flow lines. Clasts exhibit outlines and contacts suggestive of resorption by melting. The veinlets commonly have sharp contacts with the host rock. At one location we noted a pseudotachylite veinlet cut by a later, coarser-grained, clastic matrix breccia dike (Fig. 3). This cross-cutting clastic matrix brec- 


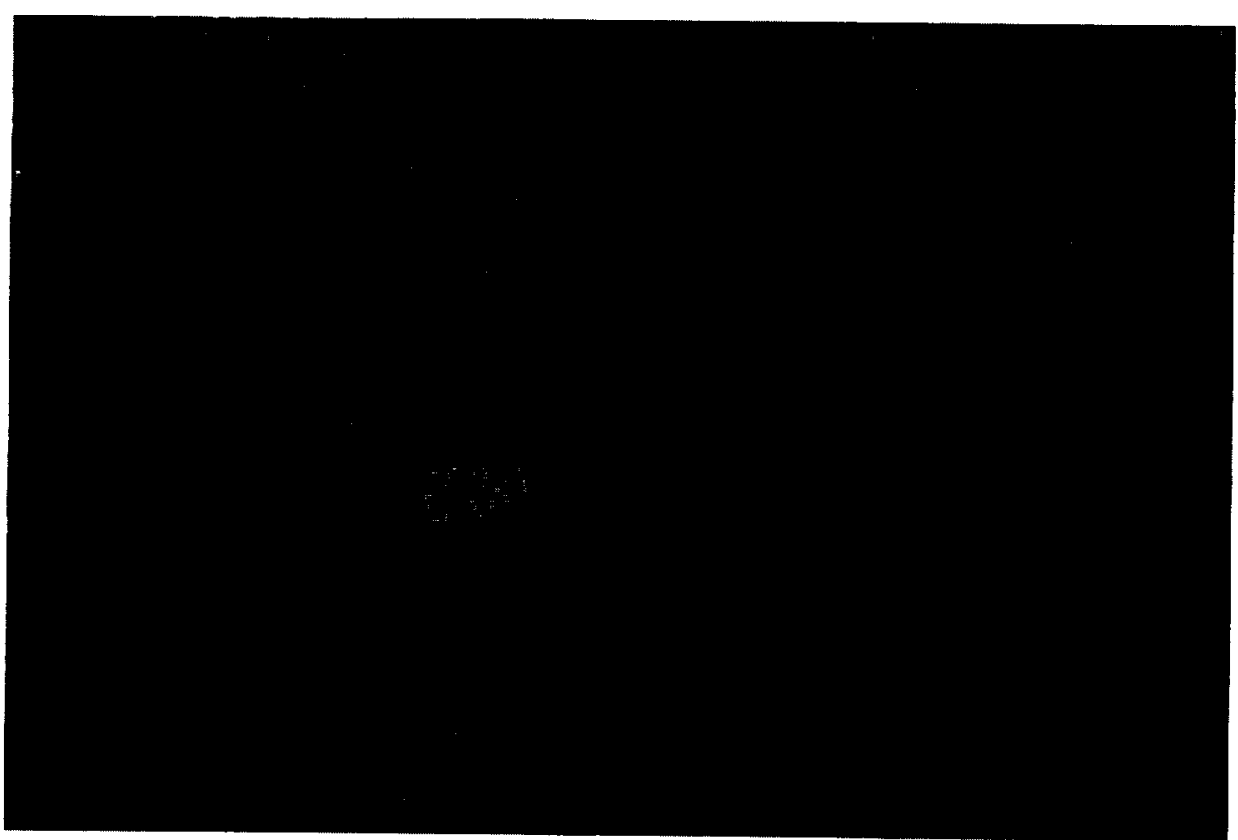

Fig. 3. Disrupted pseudotachylite veinlet $(p)$ cut by polymictic clastic matrix breccia dike $(c)$. Host rock is a fine-grained diabase. Northeastern Patterson Island. Coin has a diameter of $1.8 \mathrm{~cm}$.

cia contains fragments of the pseudotachylite vein, surprisingly little removed from where the pseudotachylite occurs in the host rock. At another location we noted a clastic matrix breccia that intruded along a pseudotachylite vein disrupting it and incorporating fragments of it (Fig. 4). We have observed up to three 'phases' of melt in one and the same pseudotachylite vein of which inclusions of the earliest-formed phase were noted in a second phase. A tiny apophysis of the third melt phase intruded the host rock of the pseudotachylite vein, but only where the host rock is cataclastically deformed (Fig. 5). The three observed phases are very similar to each other, but have distinct boundaries with each other. The first phase is darker colored than the second phase, which in turn is darker than the third phase. In all of them, tiny microlites are noted under highest microscopic magnification. The oldest pseudotachylite phase contains tiny rock fragments that exhibit features, indicative of incipient melting, devitrification and marginal resorption. Tiny quartz clasts in all three phases of the pseudotachylite were more resistant to melting than other rock-forming minerals of the host rock, a Keweenawan diabase. A few of them exhibit planar deformation features or semicircular trends of fluid inclusions. These semicircular trends resemble boundaries of ballen structures (Carstens, 1975; Bischoff and Stöffler, 1981; Sharpton et al., 1996b; Dressler et al., 1997). All phases appear to be altered. The microlites, indicating devitrification, appear to be chloritized. In other pseudotachylite samples investigated under the microscope we did not observe more than one melt phase. We have chemically analyzed matrix (the three phases combined) and host rock of the pseudotachylites described. Both host rock and pseudotachylite matrix are strongly altered and are characterized by $>10 \mathrm{wt} \%$ LOI. This does not allow us to chemically compare host rock with the pseudotachylite and makes it impossible to distinguish between an in-situ and an injection origin. In other impact structures, the composition of the pseudotachylites more or less reflects the composition of the host rock suggesting an in-situ origin (Dressler, 1984 and references therein).

\subsubsection{Polymictic clastic matrix breccias}

Polymictic clastic matrix breccias are the most common breccias on the islands. However, they are relatively scarce on Mortimer Island, Dupuis Island and the other outlying islands of the archipelago. 


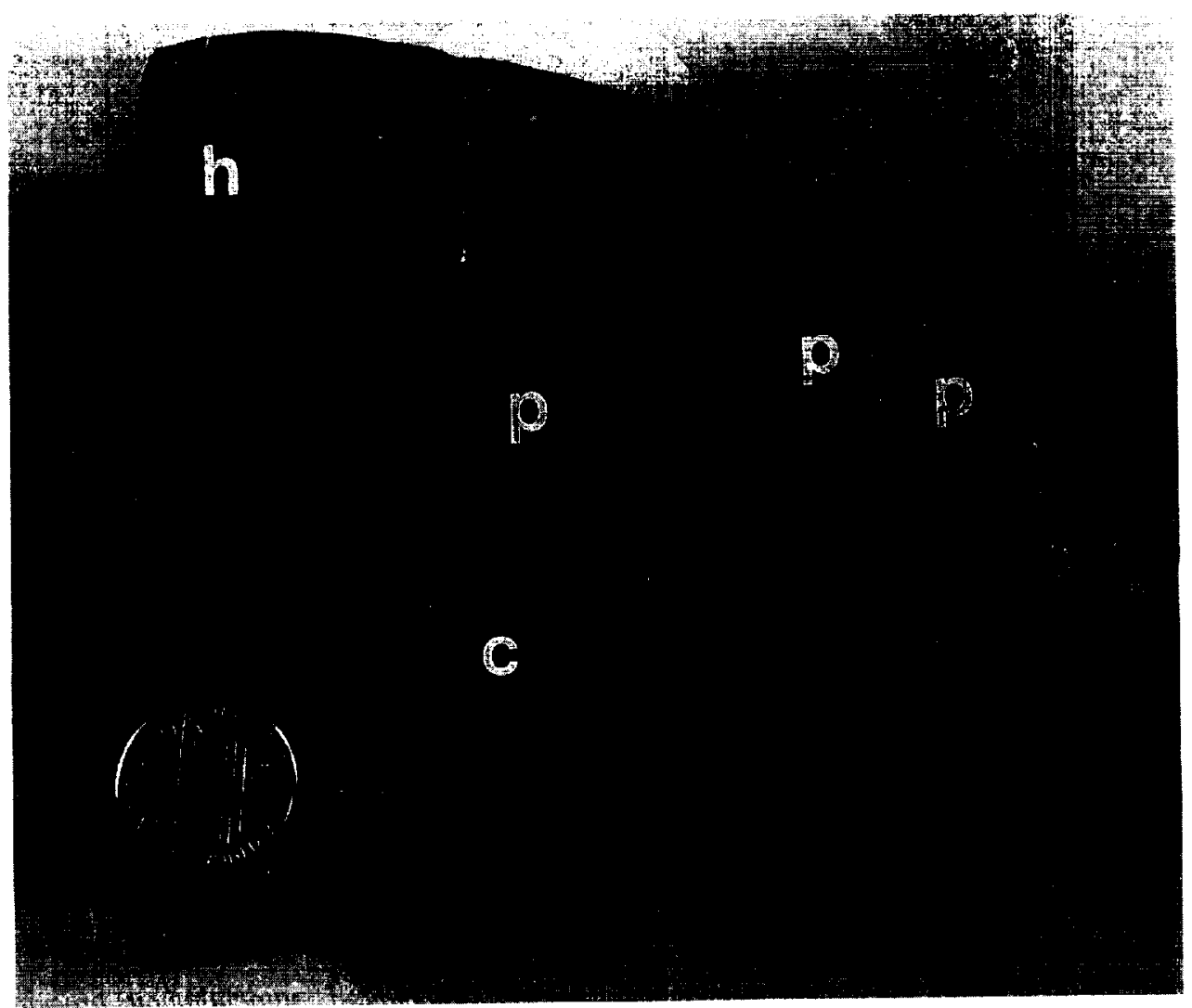

Fig. 4. Laminated, polymictic clastic matrix breccia dike $(c)$ intruding along and disrupting pseudotachylite $(p)$. Host rock $(h)$ is a fine-grained, mafic metavolcanic rock. Northeastern Patterson Island. Coin has a diameter of $1.8 \mathrm{~cm}$.

We assume that they are also present in the parautochthonous target rocks beyond the excavation cavity, away from the central uplift, but they are probably not very common there. The breccias contain a wide variety of clasts (Fig. 6) that are angular to rounded in shape and range in size from less than a millimeter to several meters. They are set in a matrix that is considerably coarser than the matrices of typical pseudotachylites. The polymictic clastic matrix breccias form dikes and irregularly shaped bodies and have sharp contacts with their host rocks. The dikes, in places, may be $>1 \mathrm{~km}$ in length. We have observed exposures of breccias 10 to $30 \mathrm{~m}$ in width. Their color is either greenish gray or, less commonly, red, depending on the color of major fragment types derived from nearby host rocks: red breccias are common on the western shore of Patterson Island and Dupuis Island, whereas the greenish-gray ones are common elsewhere. There are clast- and matrix- supported, clastic matrix breccias. All known target rocks have been observed as breccia fragments. Up to seven different target rock fragment types have been noted in a single breccia occurrence, indicating mixing of components derived from up to at least a few hundred meters distances. Iron-rich, laminated siltstone fragments are commonly observed in breccia bodies hosted by Archean target rocks. Less common are pinkish-brown siltstone and sandstone clasts. Both fragment types are derived from either the Animikie Group, the Keweenawan Supergroup. or the Jacobsville Formation, all of Proterozoic age. We have also noted, in clastic matrix breccias, fragments of pseudotachylite, rock fragments cut by pseudotachylite (Fig. 7), compound breccia fragments (Fig. 8), and shatter-coned fragments. Breccia bodies are commonly unsorted, but we have noted crudely laminated breccia dikes (Fig. 4) and dikes that contain elongate clasts oriented parallel to dike 


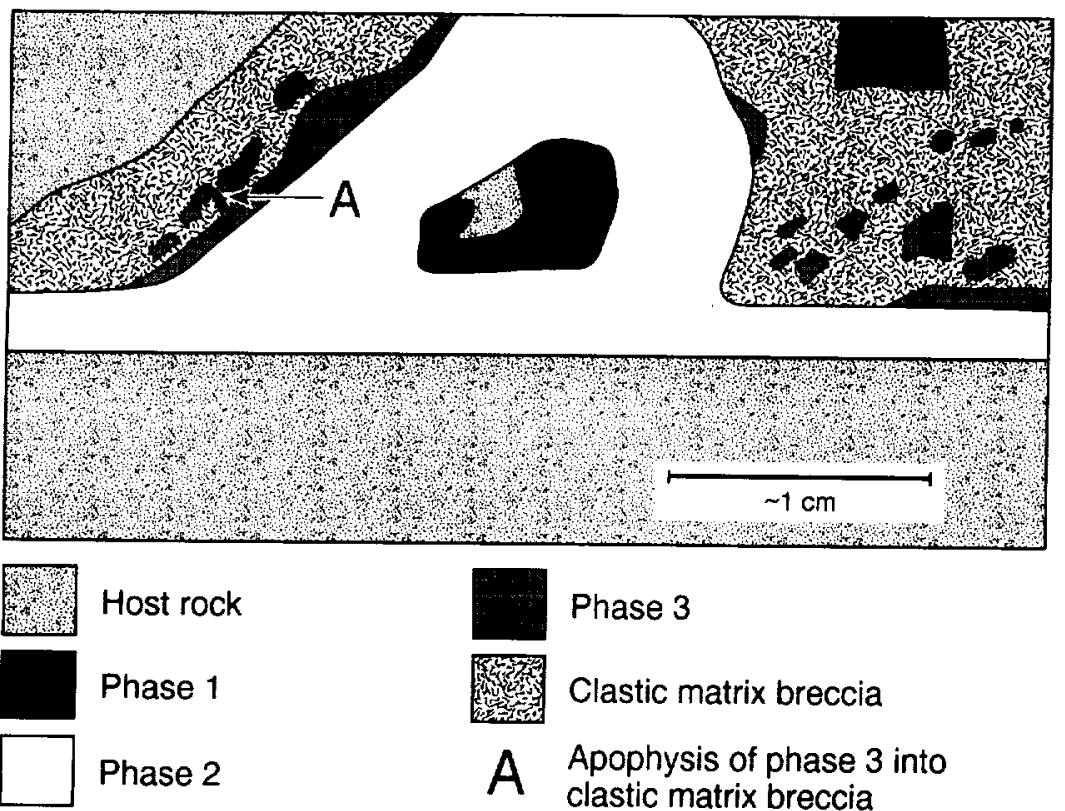

Fig. 5. Complex pseudotachylite vein showing three distinct phases (see text).

walls all across the breccia dike or only near their margins (Fig. 9). Where this is the case, unoriented clasts in the central portion of the dike are larger than at the margins, an observation made also in breccia dikes of the Manicouagan impact structure (Dressler, 1970). Our clastic matrix breccias correspond to Lambert's (1981) polymictic Type B breccias. His Type $\mathrm{B}$ breccias have clastic matrices and are either monomictic or polymictic, and have complex (Type $\mathrm{B}_{1}$ ) or simple (Type $\mathrm{B}_{2}$ ) geometry.

Most breccias contain clasts exhibiting shock metamorphic features, such as planar deformation features in quartz and some contain very scarce, altered glass or melt shards ${ }^{3}$ assumed to be of shock metamorphic origin (Fig. 10). Glass shards and fragments with planar deformation features (PDFs) may occur in breccia dikes hosted by rocks that also exhibit PDFs, but this is not the case everywhere: for example, we have noted glass shards and mineral fragments with planar deformation features in breccia dikes on Dupuis, Delaute, and Leadman islands, where host rocks apparently did not ex-

\footnotetext{
${ }^{3}$ The scarcity $(\ll 1$ vol.\%) of altered glass fragments in this breccia does not warrant the use of the term 'suevite' for these rocks. The term suevite we wish to reserve for allogenic breccias.
}

perience shock pressures sufficiently high for the formation of PDFs.

\subsubsection{Monomictic, autochthonous breccias}

Monomictic, autochthonous breccias have been observed at Mortimer Island and several of the smaller, peripheral islands. They are especially well developed on Mortimer Island, Delaute Island, and a small island east of Delaute Island (Fig. 11). On Mortimer Island, the brecciation affected Archean mafic metavolcanic rocks, on Delaute Island Proterozoic metasediments and Archean mafic metavolcanics, and on the small island east of Delaute, Proterozoic diabase. The breccias have angular, somewhat rotated fragments that are densely packed, commonly with little matrix of fine clastic rock powder between them. Here and there, fine, clastic veinlets and swirls of this fine matrix material are observed. The angular fragments are commonly up to $20 \mathrm{~cm}$ in diameter, but larger ones may also occur. The breccias have no sharp contacts with the host rocks. Fracturing extends into the country rock. Monomictic breccias, such as the ones observed on the outlying islands, appear to be very scarce on Patterson Island. Only one very small occurrence on this island, on the shore of Lawrence Bay, the large bay of northwest- 


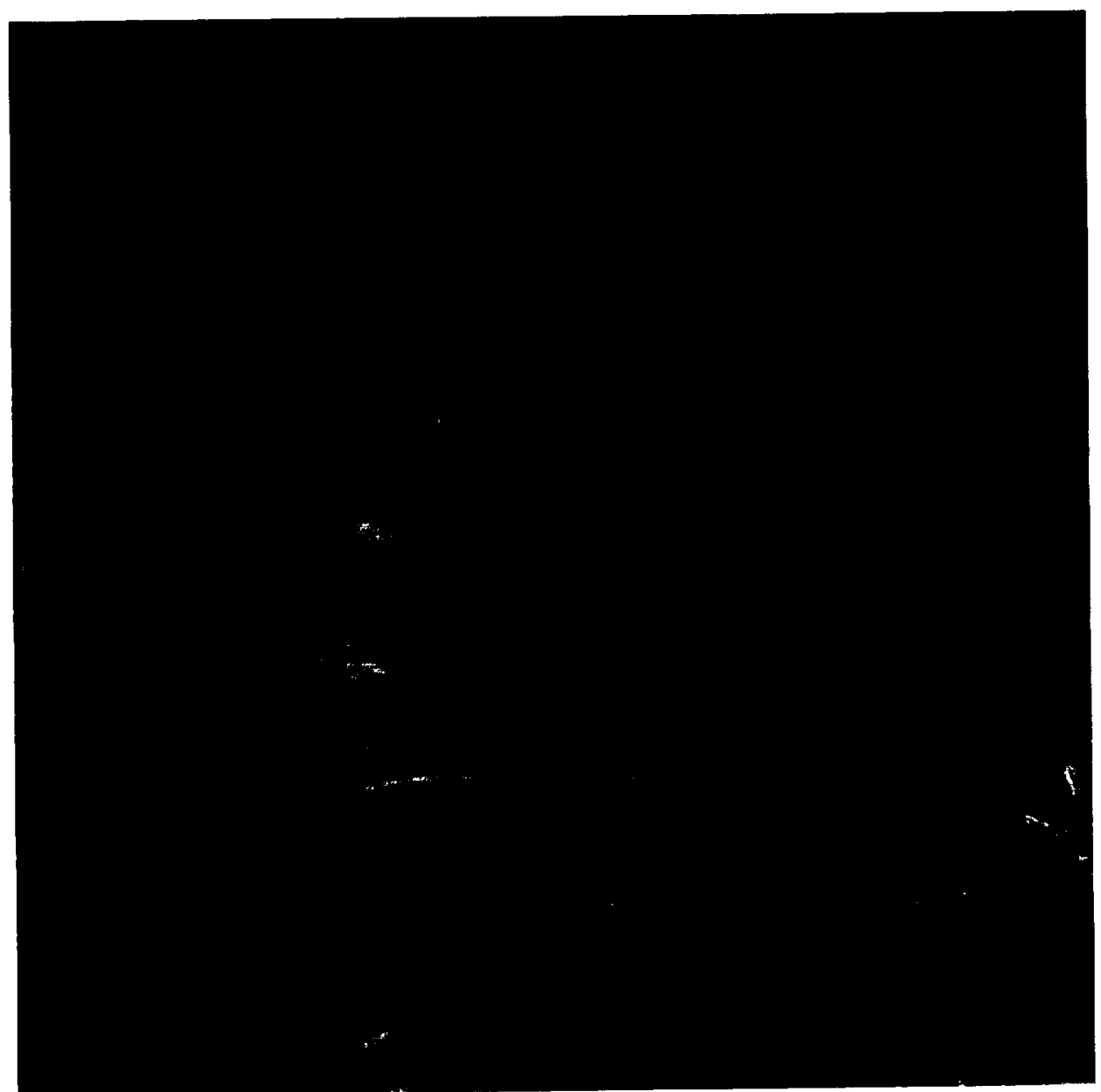

Fig. 6. Polymictic clastic matrix breccia. Clasts have various shapes and sizes and consist of a variety of Archean and minor Proterozoic target rocks. Shoreline outcrop. Patterson Island. Hammer is $33 \mathrm{~cm}$ long.

ern Patterson Island, was noted. In the central regions of Patterson Island, however, unfoliated and macroscopically unbrecciated diabase and granite occur, that, when struck with a hammer, easily break into irregular cubes and angular fragments, about 1 to 5 $\mathrm{cm}$ in size. We did not note these 'cryptic breccias' on Mortimer Island or the outlying, smaller islands.

At one location, on a small island east of and very close to Delaute Island, there is a reddish polymictic clastic matrix breccia dike enclosed in monomictic breccia. It is $\sim 25 \mathrm{~cm}$ wide and has been affected by the brecciation responsible for the formation of the monomictic breccia. The alignment of the dike clasts within the monomictic breccia, however, is still reminiscent of the original trend of the clastic matrix breccia dike. Near Lambton Cove, the central bay of Mortimer Island, there is a monomictic breccia containing fragments of pseudotachylite veinlets.

Similar breccias have been reported from other impact structures. At the Manicouagan structure, for example, Murtaugh (1976) used the term 'autochthonous breccia' for similar rocks, following Dence (1968) who used the term 'monomict, autochthonous breccias' for these rocks in the early years of investigations of impact cratering phenomena.

\subsection{Allogenic breccia deposits}

Previously, the whole island group was interpreted to represent the strongly eroded remnant of the cen- 


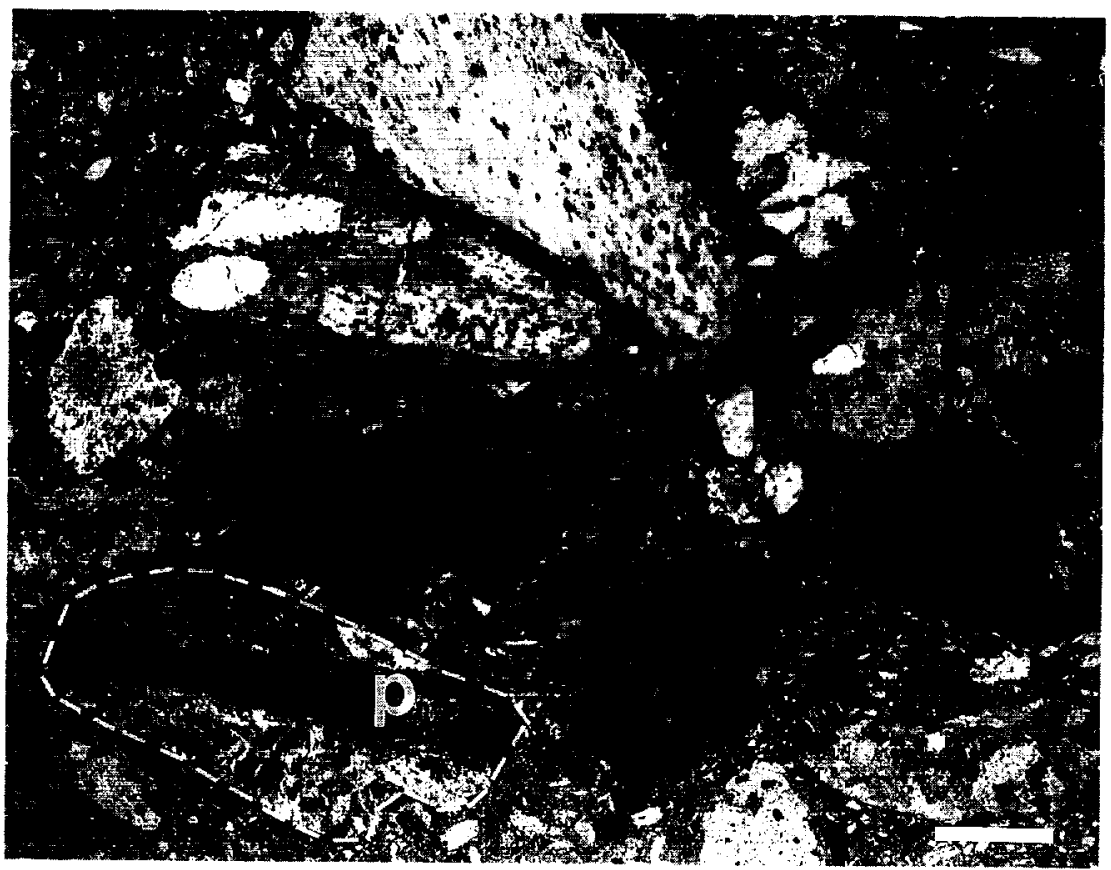

Fig. 7. Target rock fragment (felsic metavolcanic) cut by pseudotachylite vein $(p)$ in polymictic clastic matrix breccia. Fragments consist of matic and felsic metavolcanic rocks. Plane polarized light. Scale $2 \mathrm{~mm}$.

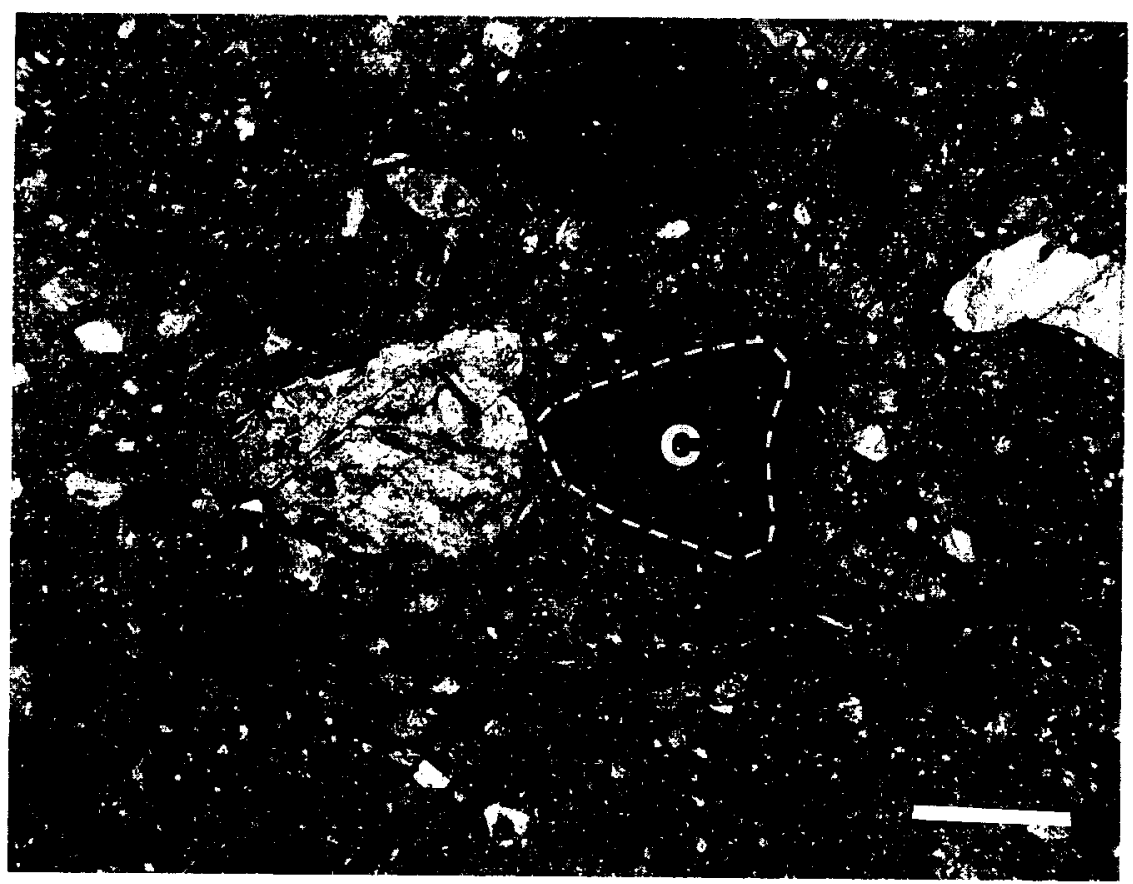

Fig. 8. Compound breccia clast ( $c$, breccia in breccia in breccia) in polymictic clastic matrix breccia. Plane polarized light. Scale $1 \mathrm{~mm}$. 


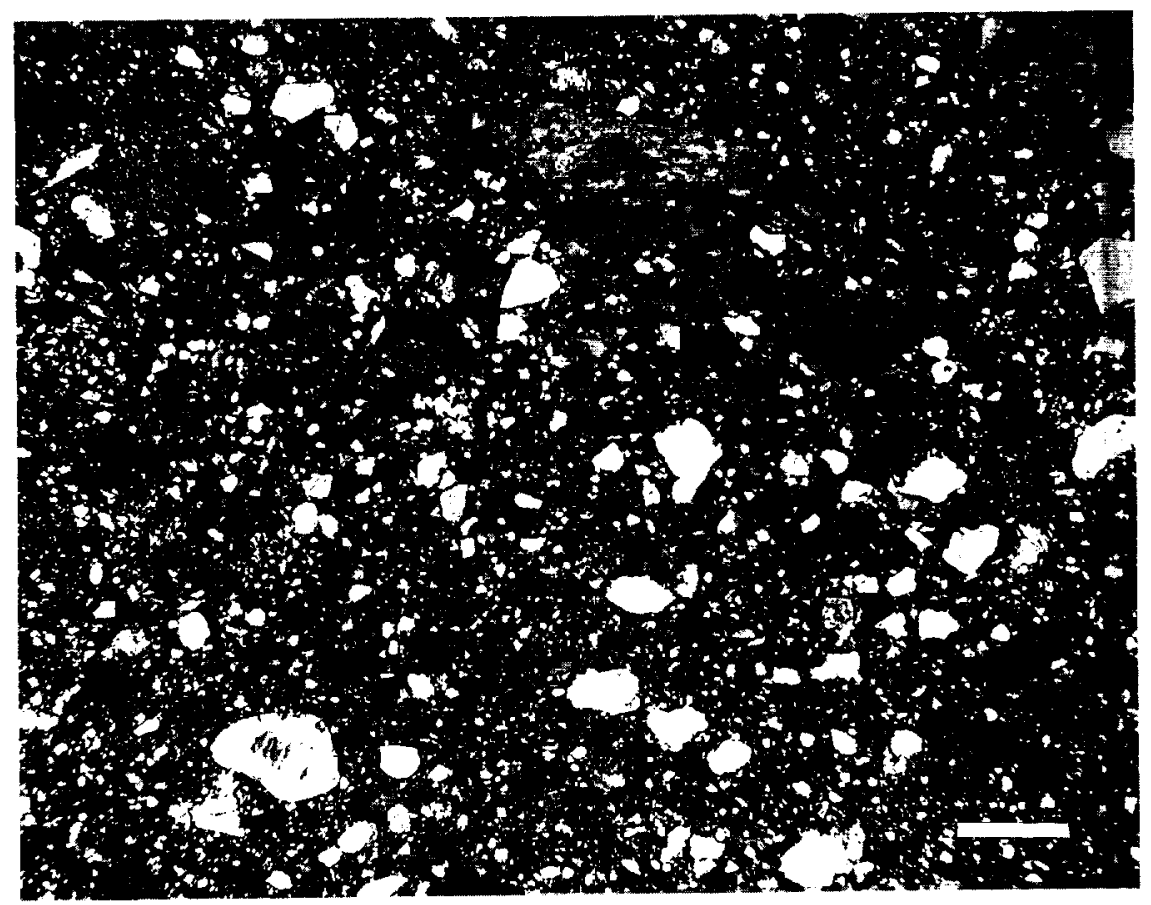

Fig. 9. Flow-aligned, polymictic clastic matrix breccia. Alignment of mafic clasts is most evident. Most felsic clasts are subrounded to angular. and show no flow alignment. Plane polarized light. Scale $2 \mathrm{~mm}$.

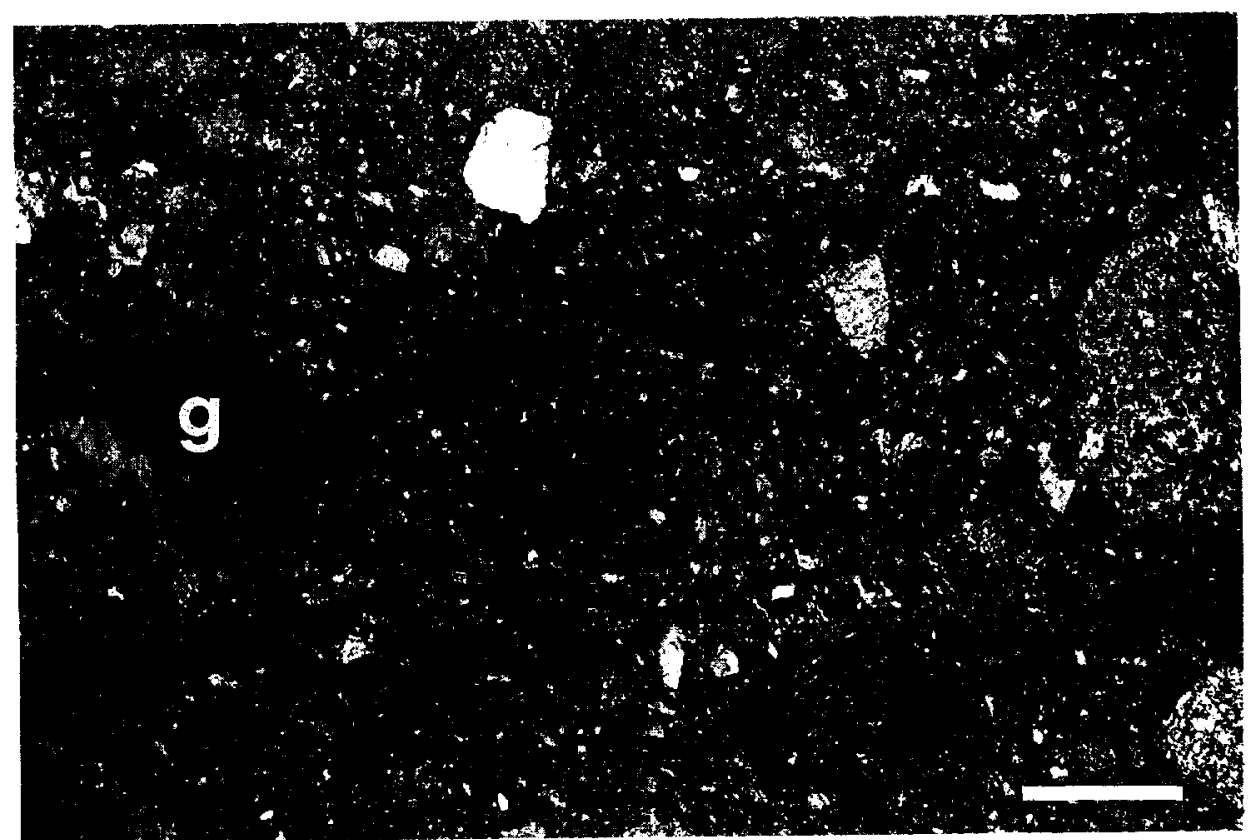

Fig. 10. Contorted, altered glass fragment $(g)$ in polymictic clastic matrix breccia. Glass fragments were observed in only very few of these breccias. Nowhere did they make up more than a fraction of $1 \%$. Plane polarized light. Scale $4 \mathrm{~mm}$. 

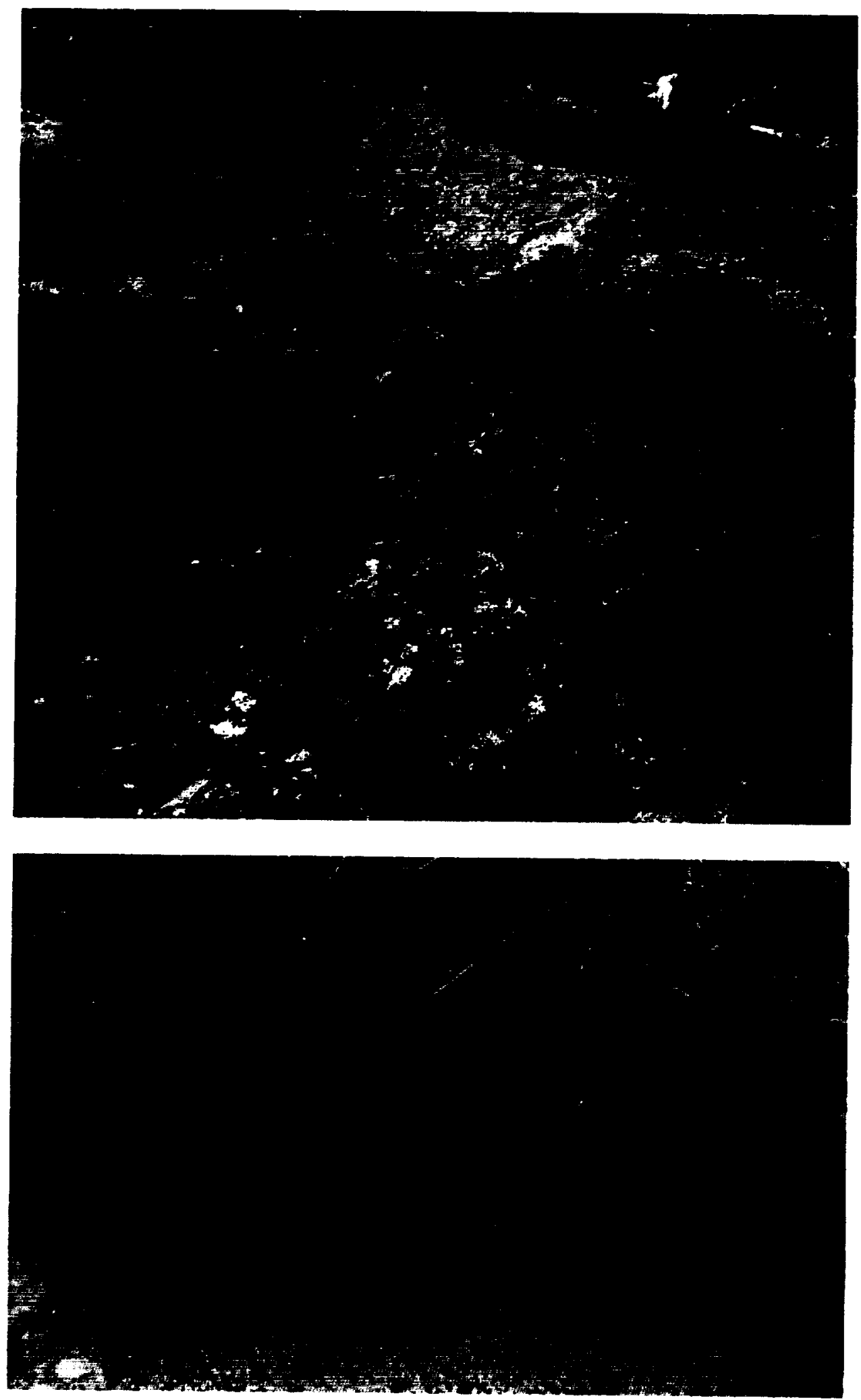
tral uplift of a complex impact crater (Halls and Grieve, 1976). In such a deep level environment, one would not expect the preservation of allogenic breccias. Recently, however, Dressler et al. (1994, 1995) and Sharpton et al. (1996a) have described allogenic breccias on Dupuis Island and in southeastern and eastern Patterson Island which led to a structural reinterpretation of the impact crater (Sharpton and Dressler, 1996; Sharpton et al., 1996a). The central uplift in this new interpretation is restricted to the more western part of Patterson Island. Two allogenic breccia types appear to be present. One contains strongly altered glass fragments, the other is devoid of glass. Following the general terminology developed from studies of allogenic breccias within other impact structures, we call the first type 'suevite', the second 'Bunte Breccia'. Outcrop conditions do not allow in all places to differentiate between allogenic breccias and breccias hosted by bedrock.

\subsubsection{Suevite}

Suevite at the type location of the Ries crater in Germany is a polymictic clastic matrix breccia containing glass fragments and rock and mineral clasts exhibiting features diagnostic of various degrees of shock metamorphism. In the 'crater suevite', glass fragments do not have aerodynamic shapes, whereas those of the fall-out suevite do (Engelhardt and Graup, 1984; Engelhardt, 1990 and references therein). At the Slate Islands structure, we have observed breccias that match the suevite classification; however, nowhere did we observe unequivocal aerodynamically shaped glass fragments. Only few suevite occurrences have been observed. This may be the result of erosion, suevite being less resistant to erosion than the Precambrian target rocks. One occurrence is in Sunday Harbour of southern Patterson Island, a few occur at the eastern shore of this island, and a small number is on Dupuis Island (Fig. 1). Polymictic clastic matrix breccia dikes that contain very minor amounts of altered glass are more common than allogenic suevite and are not classified as 'suevite' here.
As at the Ries suevite type location, the Slate Islands suevite contains a wide variety of target rock fragments, ranging in size from less than a millimeter to about $2 \mathrm{~m}$. Clasts derived from lower target stratigraphic levels are more abundant in suevite than in the 'Bunte Breccia' (cf. below). The Dupuis Island suevite, however, contains sandstone clasts that strongly resemble sandstone of the 800 Ma old Jacobsville Formation. All glass fragments in the suevite are completely altered, the alteration products, based on our microprobe work, are chlorite and smectite (Table 1). Glass fragments up to $\sim 5 \mathrm{~cm}$ long occur, but smaller ones are much more common. At the Sunday Harbour, about 8 to $10 \mathrm{~m}$ high, suevite occurrence (Fig. 13), chlorite is the alteration product in the lower portion of the occurrence, whereas smectite (Fig. 14) replaced the glasses higher up. Quartz fragments and quartz in rock clasts exhibit up to five sets of planar deformation features. The matrix of the suevite is made up by very fine-grained mineral and glass fragments. commonly too fine grained for light-microscopic identification. In Table 2 we list the modal compo-

Table 1

Composition of altered glass fragments in suevite, Sunday Harbour occurrence

\begin{tabular}{lccccc}
\hline & \multicolumn{2}{c}{ Upper suevite $^{a}$} & & \multicolumn{2}{c}{ Lower suevite $^{{ }^{a}}$} \\
\cline { 2 - 3 } & average & SD & & average & SD \\
\hline $\mathrm{SiO}_{2}$ & 53.70 & 1.20 & & 34.86 & 2.30 \\
$\mathrm{TiO}_{2}$ & 0.98 & 0.50 & 0.43 & 0.28 \\
$\mathrm{Al}_{2} \mathrm{O}_{3}$ & 29.43 & 1.29 & 17.40 & 2.14 \\
$\mathrm{FeO}$ & 2.22 & 0.11 & 16.40 & 2.19 \\
$\mathrm{MnO}$ & 0.03 & 0.03 & 0.11 & 0.02 \\
$\mathrm{MgO}$ & 1.73 & 0.26 & 20.17 & 1.03 \\
$\mathrm{CaO}$ & 0.99 & 0.60 & 0.26 & 0.05 \\
$\mathrm{Na} 2 \mathrm{O}$ & 0.95 & 0.03 & 0.20 & 0.00 \\
$\mathrm{~K}_{2} \mathrm{O}$ & 5.56 & 0.12 & 0.24 & 0.32 \\
$\mathrm{P}_{2} \mathrm{O}_{5}$ & 0.41 & 0.54 & 0.06 & 0.09 \\
Total & 96.00 & 2.47 & 90.13 & 1.25 \\
\hline
\end{tabular}

a 3 fragments; 3 microprobe analyses per fragment: Fe as $\mathrm{FeO}$ total; SD is standard deviation.

Fig. 11. Monomictic, autochthonous breccia. Angular fragments of various sizes are set in a matrix derived through strong cataclasis. Fig. 11. Monomictic, autochthonous breccia. Angular fragments of various sizes are set in a matrix derive
Contact of breccia with diabase host rock (not shown on this figure) is gradational. Small island east of Delaute Island. Pocket knife for scale.

Fig. 12. Bunte Breccia. Sunday Harbour. Clasts are angular to subrounded and consist of gray, buff and brown, fine-grained Proterozoic sandstones and siltstones. Hammer in center of photograph is $33 \mathrm{~cm}$ long. 


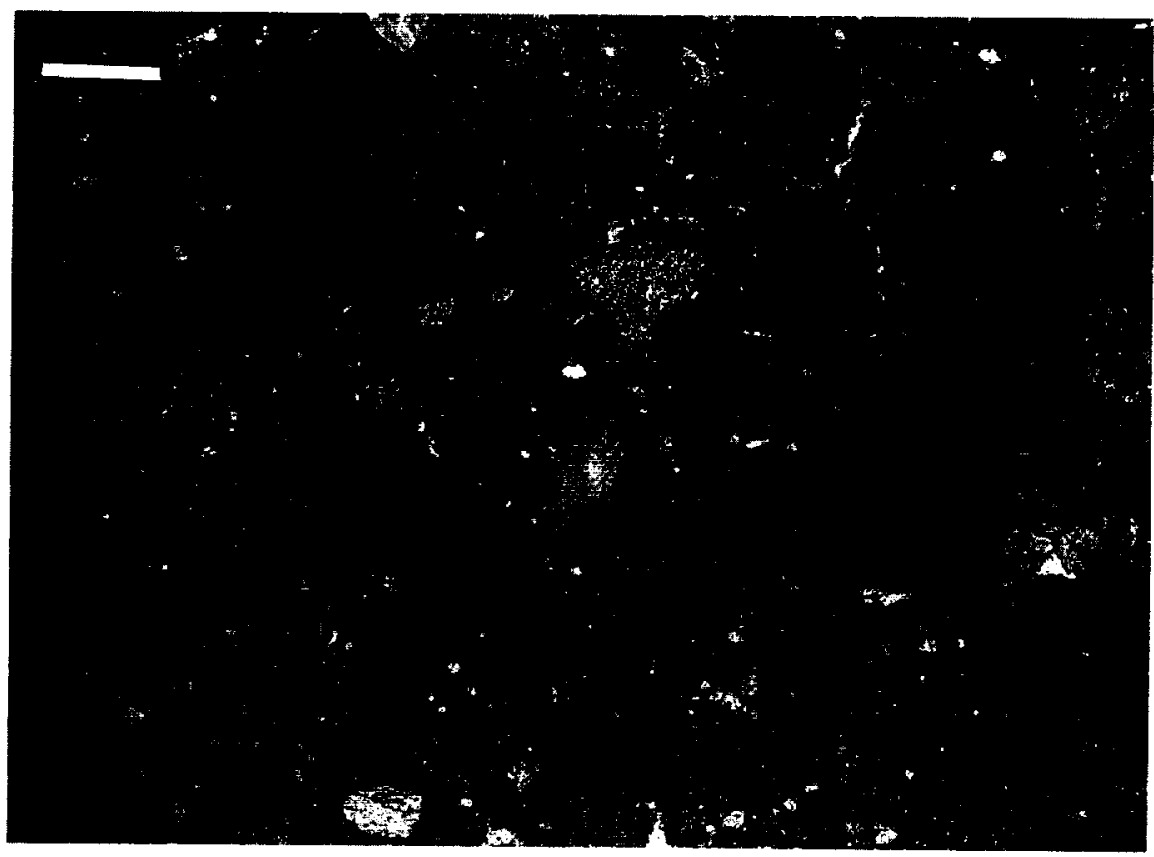

Fig. 13. Suevite. Several, tiny glass fragments (in center of circles) in polymictic clastic matrix. Plane polarized light. Sunday Harbour occurrence. Scale $2 \mathrm{~mm}$.

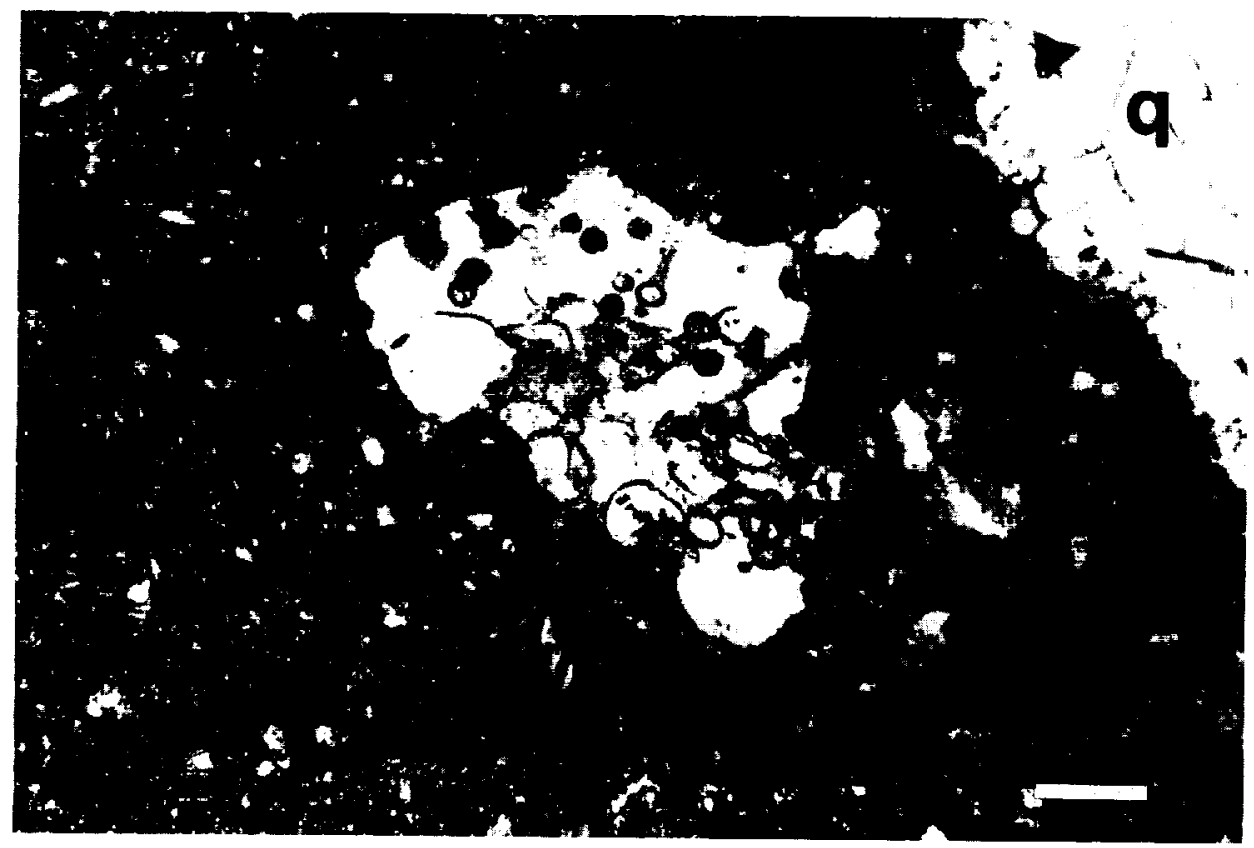

Fig. 14. Vesicular glass fragment in suevite, replaced by smectite: $q$ is quartz fragment. Plane polarized light. Sunday Harbour occurrence. Scale $0.1 \mathrm{~mm}$. 
Table 2

Modal composition of Slate Islands suevite

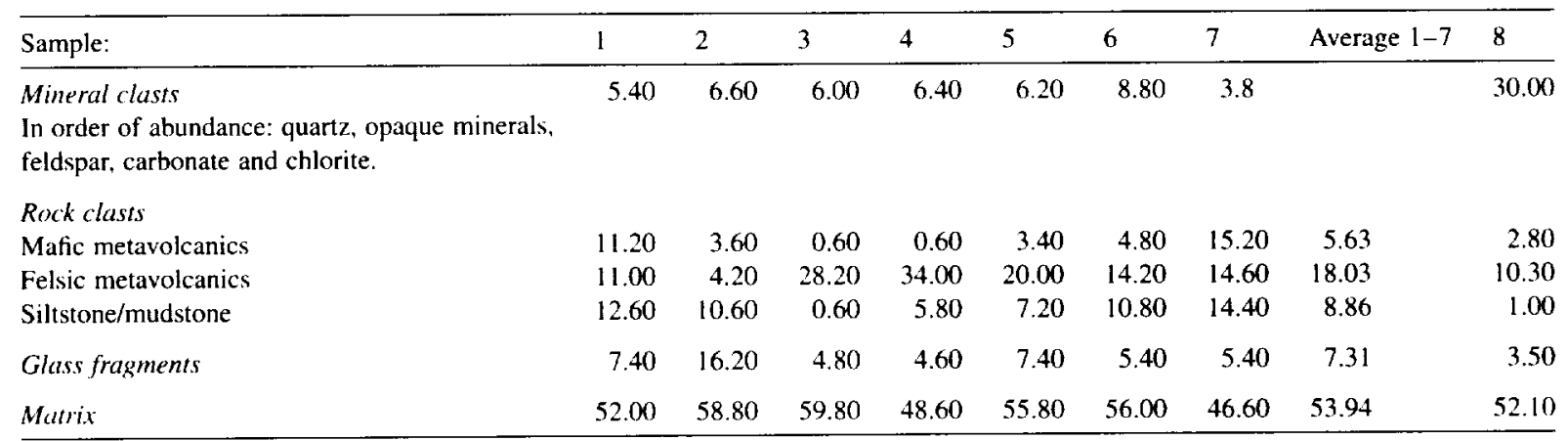

1-7: Sunday Harbour, Patterson Island; 8: Dupuis Island (Fig. 1). Matrix grain size: $<0.04 \mathrm{~mm}$.

sition of several samples of Slate Islands suevite. Large clast and matrix content vary widely. Therefore, results shown in Table 2 cannot be considered representative of all Slate Islands suevite. One result of the modal analyses, however, is significant: all investigated suevite samples are characterized by a relatively low content of altered glass.

\subsubsection{Bunte breccia}

Close to the suevite exposure in Sunday Harbour, at the same elevation above the level of Lake Superior, is an outcrop of a breccia consisting of a few large blocks of light grayish-buff, shatter-coned siltstone and pinkish sandstone. The siltstone blocks are up to $>5 \mathrm{~m}$ in size, the sandstone blocks reach only about $1 \mathrm{~m}$ in diameter (Fig. 12). Little fine-grained matrix only is present embedding the blocks, and no glass fragments or strongly shocked or mineral fragments have been observed. The gray siltstone resembles units of the Proterozoic Rove Formation known to occur on northern Mortimer Island. The pink sandstone possibly is derived from the $\sim 800$ Ma old Jacobsville Formation. Both fragment types, therefore, represent stratigraphically young target rocks. Another exposure of Bunte Breccia-type rocks is on Delaute Island where the glass-free, allogenic breccia deposit is underlain by parautochthonous, monomictic breccia. It consists mainly of Proterozoic siltstone and minor Archean rock clasts.

Macroscopically, the breccias resemble Bunte Breccia (in German, bunt is 'multicolored') of the Ries crater in Germany and correspond to "fragmental breccias' of Stöffler et al. (1988, and ref- erences therein). At the Ries, the Bunte Breccia is found around the morphological crater, up to $\sim 35$ $\mathrm{km}$ from the crater center (Hörz et al., 1977) and in the 'megablock zone' inside the crater. It contains clasts derived mainly from the upper target rock stratigraphy and local components. These local rocks from outside the crater are intermixed with clasts that were ejected ballistically (Hörz et al., 1977), or transported in a ground-surge-like mode (Chao and Minkin, 1977) from the impact crater. These local components may, in places, constitute $>90 \%$ of the volume of the Bunte Breccia (Hörz et al., 1977). Clasts derived from the crystalline basement make up from $\sim 3-10 \%$ of the total volume of the clasts (Pohl et al., 1977). Bunte Breccia components are devoid of deformation features characteristic of high levels of shock metamorphism. Clast sizes range from $<1 \mathrm{~mm}$ to $25 \mathrm{~m}$ (Hüttner, 1969). Megablocks are $\sim 25 \mathrm{~m} \sim 1 \mathrm{~km}$ in size. The Slate Islands breccia described here resembles the Bunte Breccia of the Ries, as it has no strongly shocked components and is derived from stratigraphically high target rock. However, the Bunte Breccia of the Slate Islands archipelago occurs relatively close to the center of the impact structure, clearly inside the transient crater, assuming that the size estimate for the Slate Islands structure is correct.

\section{Discussion}

The presence of shatter cones and of planar microdeformation features in the target rocks of the 
Slate Islands structure are convincing evidence that the structure was formed as a result of asteroid or comet impact. The shock deformation features in components of the breccias encountered on the islands and the presence of altered glass in the breccias strongly suggest that the breccias were formed by impact processes. These processes are very rapid processes, but cannot be considered instantaneous. Supersonic shock waves and rarefaction affect the various rock units across an impact site at slightly different times. While certain breccias form in the compression stage of an impact event, others originate during the decompression phase (i.e., excavation and central uplift) or during central uplift collapse and crater modification. It is likely that breccias formed in one stage may cut across or include clasts of another breccia of an older stage or even approximately the same stage. Irregularly shaped breccia bodies or dikes may well form and spread instantaneously at sites close enough to each other to allow cross-cutting of breccia dikes and incorporation of breccia clasts in breccias, all originally from the same breccia generation. We made observations of multiple and sequential processes in rocks of the Slate Islands structure and believe that they are all compatible with an impact origin of the structure. In the following the various breccia types described above are related to the impact process as presently understood.

\subsection{Compression stage}

Upon asteroid or comet impact, the initial, compressional shock wave forces target rocks into downward and outward motion leading to the formation of a transient crater. During this compressional stage, only more or less in-situ brecciation and melting can occur in the target material, but no large-scale brecciation involving mixing of rock fragments derived from various, far-apart locations. We believe that only pseudotachylite meets these characteristics and forms in this stage. This is not a new interpretation (Stöffler et al., 1988). Substantial resistance, however, had to be overcome during the compression stage to allow rock crushing, frictional movement and the formation of a pseudotachylite. We envision this to have happened mainly at preexisting weaknesses, such as fractures and rock contacts, as has been observed at other impact structures (e.g. Dressler, 1984). Target rocks of different densities experience different acceleration due to the passage of the shock wave and at contacts, therefore, experience tensional stress leading to crushing and eventually to melting. As these compressional stage veinlets formed more or less in situ, their chemical composition should reflect the chemical composition of their host rocks. Rock fracturing and faulting occur in probably all stages of the impact process. Even monomictic brecciation may occur in early stages, although we made no observations of this effect.

Assuming that our assignment of the pseudotachylite veinlets and dikes to the compression stage of the impact process is correct, the formation of these pseudotachylite veins is a very rapid process. Careful examination of microscopic features, however, reveals that even this rapid process is not 'instantaneous' and simple, but surprisingly very complex. As we have shown (Fig. 5), "three phases' of pseudotachylite have been observed. Furthermore, we have shown that the interior of the third phase was still liquid during the formation of the clastic matrix breccia which locally makes up the host of the pseudotachylite. The margins of the third phase were already vitrified while its interior was still liquid to allow tiny apophyses of the third phase to cut across vitrified rims and intrude the clastic breccia. In one portion of the sample described here, however, the third pseudotachylite phase had vitrified prior to the formation of the clastic matrix breccia as it forms angular fragments within this clastic breccia. Surprisingly, our petrographic observation suggests also that the formation of the clastic matrix breccia in Fig. 5 was completed prior to the complete vitrifi. cation of the melt of the third pseudotachylite phase, as the tiny apophysis of this phase is not affected by the brecciation. The various observed pseudotachylite fragments and 'phases' do not just represent one laminated pseudotachylite. They are distinct under the microscope. The homogeneous, igneous host rock of the pseudotachylite investigated here does not contain petrographic features indicative of shearing and displacement of the host rock along pseudotachylite veinlet as has been rarely observed at other impact structures, such as the Manicouagan (Dressler, 1970) and Sudbury structures (Dressler, 
1984). At the Sudbury structure, for example, there is little evidence that pseudotachylites (Sudbury Breccias) were formed solely by friction (e.g. fig. 6.8 of Dressler, 1984). The veinlet of Fig. 5 probably represents an apophysis of another, thicker vein that was formed by friction and/or impact melting. The thin veinlet of only $\sim 1-8 \mathrm{~mm}$ thickness investigated here possibly received three pulses of melt from the thicker pseudotachylite 'reservoir vein', at time intervals long enough to allow rapid vitrification of each phase within the low-temperature host rock before injection of the next phase. Pseudotachylite injection veins, branching off tabular pseudotachylite veins and dikes, have been described from impact structures (e.g. Dressler, 1984) and tectonic regimes (e.g. Sibson, 1975) supporting the tentative interpretation of our observations.

Fiske et al. (1995) generated 'pseudotachylites' in shock experiments and pseudotachylite-like rocks have been recently also produced by Spray (1995) in 2-second friction experiments. The compressional shock event experienced by the Slate Islands target rocks was probably of a shorter duration. However, readjustment of the target rocks during and after excavation, uplift and crater modification probably provided the impetus for the intrusive pulses off the reservoir vein as described above. Our observations suggest that pseudotachylite formation is a complex process and that it was rapidly followed by the generation of clastic matrix breccia, so rapidly that parts of the pseudotachylite described above had not vitrified prior to the formation of the clastic matrix breccia. Our study also shows that not only impact-induced and/or frictional melting but also the subsequent vitrification is a very rapid process.

We have also observed $\sim 2 \mathrm{~cm}$ wide pseudotachylite veins cut by about 10 to $15 \mathrm{~cm}$ wide polymictic clastic matrix breccia dikes (Fig. 3) and polymictic clastic matrix breccias intruding where pseudotachylite was formed earlier, incorporating clasts of the disrupted pseudotachylite (Fig. 4). Pseudotachylite-bearing clasts are present in polymictic clastic matrix breccias (Fig. 7). All these observations support our interpretations that pseudotachylite forms before the formation of polymictic clastic matrix breccia, presumably during the compression stage of the impact process. The petrographic results support our hypothesis that Slate Islands pseudotachylites are being formed in situ through shock-induced frictional and/or impact melting during an early stage of the impact process. In places shock pressures may have reached $>50 \mathrm{GPa}$ (Stöffler and Langenhorst, 1994) or temperatures of $1700^{\circ} \mathrm{C}$, if our interpretation is correct that some semicircular trends of fluid inclusions in quartz fragments in the pseudotachylite melt represent recrystallized ballen structures (Carstens, 1975; Bischoff and Stöffler, 1981, 1984). This possibly would suggest that the quartz fragments with these structures represent recrystallizations after lechatelierite.

Pseudotachylite formation conceivably may also occur during central uplift and other, later stages. However, we did not make any diagnostic observations that would substantiate this. At the Sudbury structure, pseudotachylite veins occur which are similar to those described here. However, most rocks described there as pseudotachylites have clastic matrices and form large, irregularly shaped, discontinuous 'Sudbury Breccia' bodies (Fairbairn and Robson, 1942; Speers, 1957; Dressler, 1984; MüllerMohr, 1992). They are randomly distributed within large, discontinuous, concentric zones, or form kmlong, non-circular dikes (Dressler, 1984; Peredery and Morrison, 1984; Thompson and Spray, 1994). In our opinion, they are probably related to the crustal rebound, large-scale modification and readjustment stages of the impact process. They contain a wide range of bedrock inclusions of which some are exotic', that is derived from other than immediate host rocks. At the Slate Islands structure, however, we did not observe pseudotachylite that we could unequivocally assign to impact stages other than the compression stage.

Pseudotachylite as described here corresponds to Lambert's (1981) Type $A_{1}$ breccias which contain few or no clasts in handspecimen, and have a cryptocrystalline, 'non-clastic' matrix, flow features and sharp contacts with host rocks. Fine-grained, laminated matrix, Type $\mathrm{A}_{2}$ breccias of Lambert (1981), have not been observed amongst our samples studied in thin section. Type A breccias, according to Lambert, formed in the shock front, during shock compression, an interpretation supported by our observations. The characteristic of some unfoliated rocks in central Patterson Island to easily break apart into 
angular fragments, when struck with a rock hammer, may be, in our opinion, a result of intense, compressive stress not conducive to rotation of fragments. Foliated rocks do not exhibit this 'cryptic brecciation'.

Relatively strong alteration of Slate Islands pseudotachylite veinlets (up to $11.29 \mathrm{wt} \% \mathrm{LOI}$ ) and of the immediate host rocks (up to $8.32 \mathrm{wt} \% \mathrm{LOI}$ ) does not allow a comparison of chemical bulk compositions that would substantiate our interpretation of an in-situ origin of the pseudotachylite. This has been done successfully in other impact structures (Speers, 1957; Murtaugh, 1975, 1976; Dressler, 1984; Reimold, 1991) where the chemical composition of the pseudotachylite reflects the composition of their host rocks.

We believe that shatter cones form early, in the compressional stage of the impact process. This interpretation is based on our observations of shatterconed clasts in allogenic breccias and in polymictic clastic matrix breccia dikes. We assign these breccias to the excavation and central uplift stages of the impact process, as described in the following.

\subsection{Excavation and central uplift}

Following the passage of a hypersonic shock wave, rarefaction, decompression, and central uplift affect the target rocks, again leading to brecciation of target rock units and of earlier formed breccias. Excavation and ejection lead to the formation of allogenic breccia deposits within the crater itself and in the area surrounding it. Decompression allows opening of fractures within the crater floor and wall rocks. As during the compressional stage of the impact process, heterogeneous targets will be subject to stronger brecciation than homogeneous targets, because of weaknesses along rock contacts, different densities of the various lithologies affected, and other heterogeneous physical rock properties. We also believe that the volume of breccias as a percentage of the total target rock volume and the shapes and sizes of breccia bodies formed in the decompression stage is strongly influenced by these rock properties. Homogeneous rock masses, such as the anorthosite body of the Manicouagan impact structure (Dressler, 1970; Murtaugh, 1975, 1976) are uplifted as large, little brecciated, shocked blocks, while heterogeneous ones break up into smaller, brecciated components (Slate Islands). It is our impression that irregularly shaped, anastomosing, inclusion-rich, polymictic breccia bodies form mainly at the boundaries of these smaller rock masses and along weaknesses within them. They cut across earlier formed pseudotachylite veins and contain inclusions of them. We estimate that $\sim 15-$ $25 \%$ of the rocks on Patterson Island are breccias, most of which are polymictic clastic matrix breccias. These clastic matrix breccias correspond to Lambert's (1981) polymictic Type B breccias in that they contain various target rock fragments in a clastic matrix.

Decompression, especially during central uplift, when target rocks are in a relatively cohesionless state of dilatation, allows for the formation of large breccia bodies between and in target rock blocks of all sizes. It also allows for the movement and mixing of breccia components, including clasts of breccia formed during the same process (Fig. 8). Movement of fragments in breccias occurs over considerable distances. The presence of clasts of Proterozoic Animikie, Keweenawan, and Jacobsville rocks in breccias hosted in Archean rocks suggests downward movement and mixing of breccia clasts over considerable distances of possibly as much as more than $5 \mathrm{~km}$, if our classification of some of the sandstone clasts as derived from the Jacobsville Formation is correct. This depth estimate is based on our interpretation of the seismic GLIMPCE Line A (Mariano and Hinze, 1994), especially of the reprocessed northern-most part of this line (courtesy of B. Milkereit, Geological Survey of Canada), where Keweenawan metabasalts just south of the central uplift form a $>5 \mathrm{~km}$ thick sequence. No Ordovician to Devonian limestone clasts have been found in the breccias on the islands, suggesting either that the structure is $>350 \mathrm{Ma}$ old or that the Phanerozoic Michigan and Hudson Bay Lowlands basins were not connected across Lake Superior, as advocated by Norris and Sanford (1968). Downward movement of clasts in impact breccias into crater basements has also been observed at other terrestrial impact craters, for example the Ries crater in Germany (Stöffler, 1977).

The presence of glass in polymictic clastic matrix breccia on Dupuis and Leadman islands suggests that 


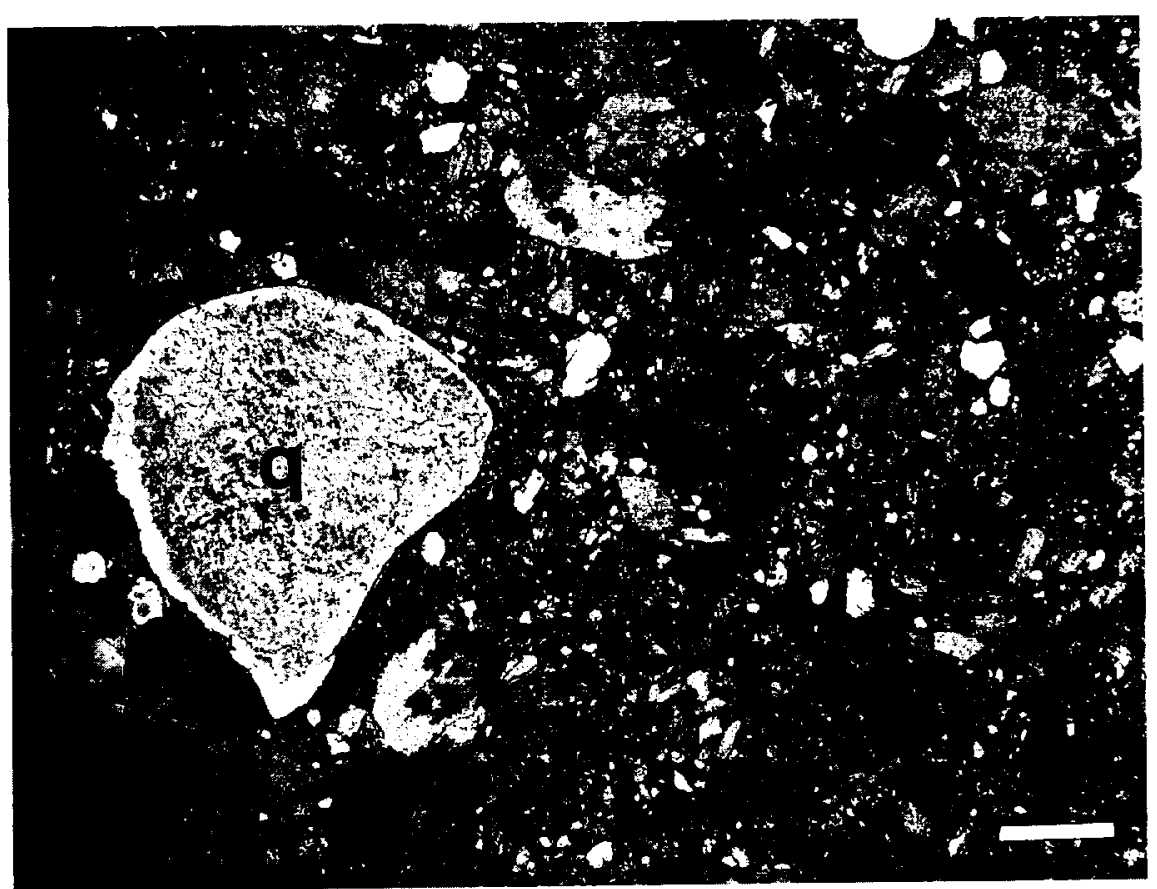

Fig. 15. Post-impact recrystallization of rim of quartz grain (q) in polymictic clastic matrix breccia. Plane polarized light. Scale 2 mm.

fragment transport, in addition to substantial downward transport, was mainly away from the center of the impact. Our observations indicate fragment transport of distances of up to and possibly $>2 \mathrm{~km}$. This is the distance between the east shore of Patterson Island, where high shock pressure features are common in the target rocks, to the breccia dikes on the main island of the Leadman Islands group that contain fragments with planar deformation features in quartz. The target rocks at the Leadman Islands do not contain these features. Similar observations at the Manicouagan structure support our interpretation. Near the periphery of this structure, close to the northeast shore of Mushalagane Lake, clastic matrix breccia dikes ('red suevite') were observed before the filling of the Manicouagan reservoir that have characteristics similar to those just described. The host rocks have no features indicating strong shock deformation but the breccias contain fragments with planar deformation features and fragments of rocks that are not known to outcrop in the vicinity of the 'red suevite' dikes (Dressler, 1970, 1990).

All our diagnostic observations indicate that the polymictic clastic matrix breccias formed after the formation of pseudotachylite and the compression phase of the impact process. We did not make any observations that would suggest that they also formed during the later crater modification phase.

Suevite found in a few places on the islands is relatively glass-poor and glass fragments do not exhibit aerodynamic shapes. These are characteristics of fall-back, crater suevite (Pohl et al., 1977; Engelhardt and Graup, 1984; Engelhardt, 1990 and references therein). They are in good agreement with the location of the observed suevite deposits at what we believe are the flanks of the central uplift or the annular trough around the uplift (Sharpton and Dressler, 1996). Fall-out suevite deposits are probably present beneath the waters of Lake Superior around the island group. On the mainland to the north they have been removed by erosion.

Ejected breccia deposits derived mainly from the upper target stratigraphy, and loosely termed Bunte Breccia here in analogy to breccias at the Ries crater, have also been eroded on the northern mainland. There is one Bunte-Breccia-like outcrop in Sunday Harbour of Patterson 1sland, and another one on Delaute Island. The Sunday Harbour location may be at the flanks of the central uplift or, as the Delaute island occurrence, at the inner, annular trough of 


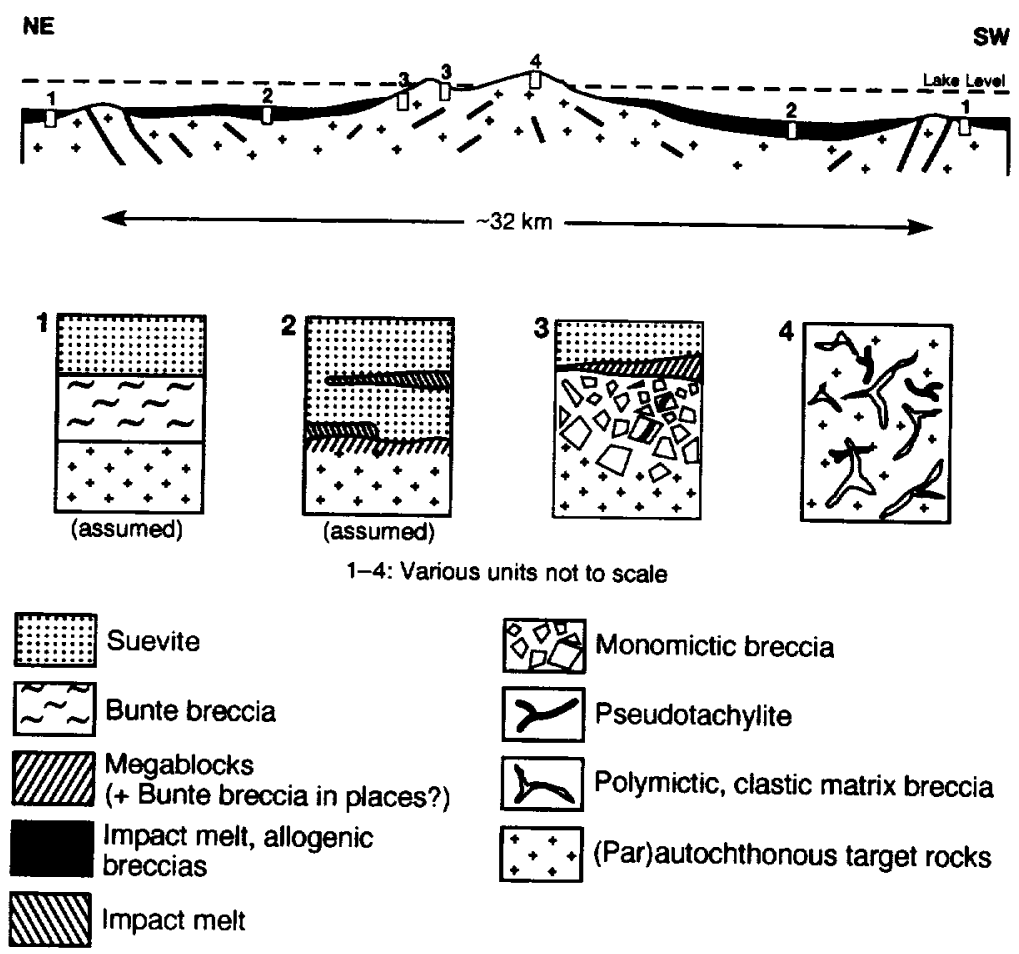

Fig. 16. Section across the Slate Islands complex impact structure showing distribution of breccias investigated. Minor polymictic clastic matrix breccias are present also further away from the center of the structure than shown here. Profile is based on bathymetric information from around the archipelago and on topographic maps of the islands. Compare with Fig. 2.

the Slate Islands complex impact structure (Sharpton and Dressler, 1996).

\subsection{Crater modification}

Following central uplift and excavation, collapse of the central peak or peak ring and the walls of the transient crater result in the formation of fractures and possibly the rotation of parautochthonous megablocks. Late fracturing probably would be strongest at these locations within the impact structure. We would expect to see earlier formed breccias, such as pseudotachylite and polymictic clastic matrix breccias, to be affected by this late fracturing process. In two places we were able to make observations diagnostic to that effect. At Mortimer Island, in Lambton Cove, there are pseudotachylite veinlets that have been affected by late monomictic brecciation, as have polymictic clastic matrix breccia dikes on a small island west of Delaute Island. Therefore, we believe that most or all monomictic breccias form late in the impact process. We did not make any diagnostic observation that would suggest that they also form during an earlier phase: we did not observe monomictic breccia bodies cut by pseudotachylite or polymictic clastic matrix dikes. Our 'cryptic breccias', however, are believed to have formed during the compression stage.

\subsection{Post-impact modifications}

In terrestrial impact structures, following crater modification, hydrothermal alteration affects breccias to various degrees. This has been observed at several structures, such as the Ries crater in Germany (Engelhardt, 1990 and references therein), the Rochechouart structure in France (Bischoff and Oskierski, 1987), and others (e.g. Boer et al., 1996; McCarville and Crossey, 1996). At the Slate Islands structure similar alterations were noted by us. Impact glasses were all replaced by either chlorite or smectite. Pseudotachylite veinlets have whole-rock 
Table 3

Slate islands impact breccias

\begin{tabular}{|c|c|c|c|c|}
\hline \multicolumn{5}{|c|}{ Slate Islands Impact Breccias } \\
\hline \multirow[t]{6}{*}{ Impact Phase } & Compression & Excavation/Central Uplift & Modincation & Long-term Readjustment \\
\hline & \multicolumn{4}{|c|}{ Faulting } \\
\hline & \multirow[b]{4}{*}{ Pseudotachylite } & Allogenk BX & & \multirow[b]{4}{*}{ (BX: Breccia) } \\
\hline & & & Monomictic BX & \\
\hline & & \multirow[t]{2}{*}{ Polymictlc Clastic Matrix BX } & & \\
\hline & & & & \\
\hline Time (s) & & \multicolumn{2}{|c|}{$10^{1}-10^{2}$} & $>10^{3}$ \\
\hline Breccia type & \multicolumn{3}{|c|}{ Diagnostic observations } & Impact stage \\
\hline \multicolumn{4}{|l|}{ Breccias in target rocks } & \multirow[b]{2}{*}{ Compression } \\
\hline Pseudotachylite & \multicolumn{3}{|c|}{$\begin{array}{l}\text { Fluidal melt texture; thin dikelets and anastomosing veins; } \\
\text { sharp contacts with host rocks; few clasts, some with shock } \\
\text { features. Relatively scarce, observed on Patterson and } \\
\text { Mortimer islands. }\end{array}$} & \\
\hline 'Cryptic breccia' & \multicolumn{3}{|c|}{$\begin{array}{l}\text { Homogeneous rock that breaks into small, angular fragments when } \\
\text { struck with a rock hammer. Central Patterson Island only. }\end{array}$} & Compression \\
\hline $\begin{array}{l}\text { Polymictic clastic } \\
\text { matrix breccia }\end{array}$ & \multicolumn{3}{|c|}{$\begin{array}{l}\text { Wide variety of clasts of various shapes and sizes: shock } \\
\text { metamorphic features; altered glass in places; fragments of } \\
\text { pseudotachylite in places; forms dikes and irregularly shaped } \\
\text { bodies with sharp contacts with host rocks; cuts across } \\
\text { pseudotachylite. All islands, but mainly on Patterson Island. }\end{array}$} & $\begin{array}{l}\text { Central uplift and excavation; } \\
\text { possibly also somewhat later. }\end{array}$ \\
\hline Monomictic breccia & \multicolumn{3}{|c|}{$\begin{array}{l}\text { Monomictic, angular fragments in clastic matrix; transitional } \\
\text { contacts with host rocks; contains fragmented, polymictic, } \\
\text { clastic matrix breccia dikes. Mortimer Island and outlying } \\
\text { islands only. Very scarce on Patterson Island. }\end{array}$} & Crater modification \\
\hline \multicolumn{4}{|l|}{ Allogenic breccias } & \multirow{2}{*}{ Excavation } \\
\hline Suevite & $\begin{array}{l}\text { Shock metamorp } \\
\text { matrix. Glass fra } \\
\text { east Patterson Is }\end{array}$ & $\begin{array}{l}\text { c clasts and altered glass fragme } \\
\text { ments have no aerodynamic shap } \\
\text { id and Dupuis Island only. }\end{array}$ & South and & \\
\hline 'Bunte Breccia' & \multicolumn{3}{|c|}{$\begin{array}{l}\text { Polymictic, glass-free breccia. No features indicative of } \\
\text { strong shock. South Patterson and Delaute islands. }\end{array}$} & Excavation \\
\hline
\end{tabular}

chemical compositions with almost $12 \mathrm{wt} \%$ loss on ignition and elementary changes suggesting chloritization. Some breccia dikes have much carbonate in their matrices, not only reflecting post-impact alteration but also incorporation of carbonate from pre-impact carbonatized metavolcanic rocks. Breccia components, in places, exhibit signs of post-brecciation recrystallization as shown in Fig. 15. All these observations provide evidence that relatively warm fluids were percolating within the breccias, be they in dike form or be they fall-back deposits.

\section{Conclusions}

We have described a variety of polymictic and monomictic breccias from the Slate lslands impact structure and related them to the various stages of the impact process. The distribution of the various breccia types is schematically shown in Fig. 16. Polymictic clastic matrix breccias are prominent on Patterson Island, whereas monomictic breccias are mainly found on the outlying islands of the archipelago. We did not observe any breccias near 
the northern crater rim, assumed to lie on the mainland north of the island group. This is possibly the result of erosion. Wiest (1987), for example, has reported an increase of brecciation near the rim fault zone of the Carswell complex impact structure in Saskatchewan, Canada. In Table 3 we summarize our observations and interpretations. Pseudotachylite and shatter cones form during the compressional stage, polymictic clastic matrix breccia dikes with and without glass fragments during the decompression, excavation and central uplift stages, and monomictic, parautochthonous breccias during the crater modification stage. Suevitic breccias and Bunte-Brecciatype rocks represent ejecta fall-back deposited at the flanks of the central uplift or in the annular trough around the central uplift. They are probably also present beneath the waters surrounding the Slate Islands archipelago.

Polymictic clastic matrix breccias are formed possibly also during the early crater modification stage. Likewise, breccia types, which we have assigned to the compressional stage of the impact process, may have very similar, conceivably identical, counterparts that were formed in a later stage. However, we did not make any diagnostic observations to this effect.

Our observations also provide answers to some criticism from traditional geoscientists, who were in the past at odds, and in some cases still are, with apparently contradictory field observations of 'obviously multiple and sequential geological processes' recognizable in the record provided by impact rocks and the understandable preconception of a traditional geoscientist, on what characteristics the rocks and rock units should have that are formed by a rapid, catastrophic, and chaotic process such as planetary impact. Observations of breccia clasts in breccias, of one breccia dike cutting across an 'older' one, or the observation of sharp contacts within impact ejecta deposits, for example, were seen as evidence for sequential processes, one following the other, possibly with considerable time intervals between them. Therefore, these observations were in the past sometimes understandably advanced as evidence against interpretation of rock sequences as formed by impact. In consequence, geological structures characterized by these sequences could not be impact sites (for example Muir, 1984). As we have shown, there are cross-cutting breccia dikes and breccia clasts in breccias and other features in the rocks at the Slate Islands impact structure that are suggestive of sequential processes. However, they were all formed during one catastrophic impact process.

\section{Acknowledgements}

We thank John Wood, Director, Ontario Geological Survey, for the generous logistical support for our 1994 and 1995 field investigations. We received all possible assistance from staff of the Ministry of Natural Resources, Terrace Bay, Ontario, including essential radio communication services. We are grateful for many stimulating discussions with our colleagues R.R. Herrick, K. Klaus, B. Schnieders, J. Scott, and B.C. Schuraytz who also provided competent field assistance. S. Hokanson assisted in preparation of graphics. The paper benefited from the excellent reviews by Drs. L. Bischoff, B. French and W.U. Reimold. Parts of this research were made possible through research grants provided by the United States National Aeronautics and Space Administration's Planetary Geology and Geophysics Program. The Lunar and Planetary Institute is operated by the University Space Research Association under Contract NASW-4574 with NASA. This is Lunar and Planetary Institute Contribution 903.

\section{References}

Bischoff, A., Stöffer, D., 1981. Thermal metamorphism of feldspar clasts in impact melts from Lappajärvi crater, Finland (Abstr.). Lunar Planet. Sci. Conf. 12, 77-79.

Bischoff, A., Stöffler, D., 1984. Chemical and structural changes induced by thermal annealing of shocked feldspar inclusions in impact melt rocks from Lappajärvi crater, Finland. J. Geophys. Res. Suppl. 89, 645-656.

Bischoff, L., Oskierski, W., 1987. Fractures, pseudotachylite veins and breccia dikes in the crater floor of the Rochechouart impact structure, SW-France, as indicators of crater forming processes. In: J. Pohl (Ed.), Research in Terrestrial Impact Structures. Vieweg, Braunschweig/Wiesbaden, pp. 5-29.

Boer, R.H., Reimold, W.U., Koeberl, C., Kesler, S.E., 1996 Fluid inclusion studies on drill core samples from the Manson impact crater: evidence for post-impact hydrothermal activity. In: C. Koeberl, R.R. Anderson (Eds.), The Manson Impact Structure, Iowa: Anatomy of an Impact Structure. Geol. Soc. Am., Spec. Pap. 301, 347-376.

Card, K.D., Sanford, B.V. and Davidson, A., 1994. Bedrock geology, Lake Superior, Ontario, USA, Map NL-16/17-G. 
Natural Resources Canada.

Carstens, H., 1975. Thermal history of impact melt rocks in the Fennoscandian Shield. Contrib. Mineral. Petrol. 50, 145-155.

Chao, E.C.T., Minkin, J.A., 1977. Impact cratering phenomenon for the Ries multiring structure based on constraints of geological, geophysical, and petrological studies and the nature of the impacting body. In: D.J. Roddy, R.O. Pepin and R.B. Merrill (Editors), Impact and Explosion Cratering. Pergamon Press, New York, pp. 405-424.

Dence, M.R., 1968. A comparative structural and petrographic study of probable Canadian meteorite craters. Meteoritics 2 , 249-270.

Dence, M.R.. 1972. The nature and significance of terrestrial impact structures. 24th Int. Geol. Congr., Montreal. pp. 77-89.

Deutsch, A., Grieve, R.A.F., Avermann, M., Bischoff, L., Brockmeyer, P., Buhl, D., Lakomy, R., Müller-Mohr, V., Ostermann, M., Stöfler, D., 1995. The Sudbury Structure (Ontario, Canada): a tectonically deformed multi-ring impact basin. Geol. Rundsch. 84, 697-709.

Dressler, B., 1970. Die Beanspruchung der präkambrischen Gesteine in der Kryptoexplosionsstruktur von Manicouagan in der Provinz Quebec, Canada. Unpubl. Ph.D. Thesis, Univ. München, $108 \mathrm{pp}$.

Dressler, B.O.. 1984. The effects of the Sudbury event and the intrusion of the Sudbury Igneous Complex on the footwall rocks of the Sudbury Structure. In: E.G. Pye. A.J. Naldrett and P.E. Giblin (Editors), The Geology and Ore Deposits of the Sudbury Structure. Ont. Geol. Surv., Spec. Pap. 1, 97-136.

Dressler, B., 1990. Shock metamorphic features and their zoning and orientation in the Precambrian rocks of the Manicouagan Structure, Quebec, Canada. Tectonophysics 171, 229-254.

Dressler, B.O.. Morrison, G.G., Peredery, W.V., Rao, B.V., 1987. The Sudbury Structure, Ontario, Canada - a review. In: J. Pohl (Editor). Research in Terrestrial Impact Structures. Vieweg. Braunschweig/Wiesbaden, pp. 39-68.

Dressler, B.O., Sharpton, V.L., Schuraytz. B., Scott, J., 1994 Bunte breccia. impact melt and suevite at the Slate Islands impact structure, Ontario. Ont. Geol. Surv.. Misc. Pap. 163, 59-61.

Dressler, B.O., Sharpton, V.L., Schnieders, B., Scott, J., 1995. New observations at the Slate Islands impact structure, Lake Superior. Ont. Geol. Surv., Misc. Pap. 164, 53-61.

Dressler, B.O., Crahtree, D., Schuraytz, B.C., 1997. Incipient melt formation and devitrification at the Wanapitei impact structure, Ontario, Canada. Meteoritics Planet. Sci.. in press.

Engelhardt, W.v., 1990. Distribution, petrography and shock metamorphism of the ejecta of the Ries crater in Germany - a review. Tectonophysics 171, 259-273.

Engelhardt, W.v., Bertsch, W.. 1969. Shock induced planar deformation structures in quartz from the Ries crater. Contrib. Mineral. Petrol. 20, 203-224.

Engelhardt, W.v., Graup, G., 1984. Suevite of the Ries crater, Germany: source rocks and implications for cratering mechanics. Geol. Rundsch. 73, 447-481.

Fairbairn, H.W.. Robson, G.M., 1942. Breccia at Sudbury, Ontario. J. Geol. 50, 1-33.

Fiske, P.S., Nellis, W.J., Lipp, M., Lorenzana, H., Kikuchi,
M., Syono, Y.. 1995. Pseudotachylites generated in shock experiments: implications for impact cratering products and processes. Science 270, 281-283.

Floran, R.J., Grieve, R.A.F., Phinney, W.C., Wamer, J.L., Simonds, C.H., Blanchard, D.P., Dence, M.R., 1978. Manicouagan impact melt, Quebec, 1. Stratigraphy, petrology, and chemistry. J. Geophys. Res. 83, 2737-2759.

French, B.M., Short, N.M. (Editors), 1968. Shock Metamorphism of Natural Materials. Mono Book Corp.. Baltimore, $644 \mathrm{pp}$.

Grieve, R.A.F., Robertson. P.B., 1976. Variations in shock deformation at the Slate Islands impact structure, Lake Superior, Canada. Contrib. Mineral. Petrol. 58, 37-49.

Grieve, R.A.F., Stöffler, D.. Deutsch, A., 1991. The Sudbury Structure: controversial or misunderstood?. J. Geophys. Res. $96,22753-22764$

Grieve, R., Rupert. J., Smith, J., Therriault, A., 1995. The record of terrestrial impact cratering. Geol. Soc. Am. Today, 5, pp. 189. 194-196.

Grieve, R.A.F., Langenhorst, F., Stöffler, D., 1996. Shock metamorphism of quartz in nature and experiment. II. Significance in geoscience. Meteoritics Planet. Sci. 31, 6-35.

Halls, H.C., Grieve, R.A.F., 1976. The Slate Islands: a probable complex meteorite impact structure in Lake Superior. Can. J. Earth Sci. 13, 1301-1309.

Henkel, H., Reimold, W.U., 1966. Integrated gravity and magnetic modelling of the Vredefort impact structure - reinterpretation of the Witwatersrand Basin as the erosional remnant of an impact basin. Economic Geology Res. Unit, University of the Witwatersrand, Johannesburg. Information Circular 299 $89 \mathrm{pp}$.

Hörz, F. Gall, H., Hüttner, R., Oberbeck, V.R., 1977. Shallow drilling in the 'Bunte Breccia' impact deposits, Ries Crater. Germany. In: D.J. Roddy, R.O. Pepin and R.B. Merrill (Editors). Impact and Explosion Cratering. Pergamon Press, New York, pp, 425-448.

Hüttner, H., 1969. Bunte Trümmermassen und Suevit. Geol. Bavarica 61, 142-200.

Kamo, S.L., Reimold, W.U., Krogh, T.E., Colliston, W.P., 1995 Shocked zircon in Vredefort pseudotachylite and the U-Pb zircon age of the Vredefort impact event. In: Extended Abstracts Centenary Geocongress (Geocongress '95) of the Geological Society of South Africa, Johannesburg, 5660569

Lambert, P., 1981. Breccia dikes: geological constraints on the formation of complex craters. In: Multi-ring Basins. Proc. Lunar Planet. Sci. Conf. 12A, 56-78.

Magloughlin, J.F., Spray, J.G., 1992. Frictional melting processes and products in geological materials: introduction and discussion. Tectonophysics 204. 197-206.

Mariano, J.. Hinze, W.J., 1994. Structural interpretation of the Midcontinental Rift in eastern Lake Superior from seismic reflection and potential field studies. Can. J. Earth Sci. 31 . 619-628.

Martini, J.E.J., 1991. The nature, distribution and genesis of the coesite and stishovite associated with pseudotachylite of the Vredefort Dome. South Africa. Earth Planet. Sci. Lett. 103. 203-300.

Masaitis, V.L., Mashchak, M.S., Naumov, M.V., Raikhlin, A.I., 
1994. Large Astroblemes of Russia. All-Russian Geological Research Institute (VSEGEI), St. Petersburg, $32 \mathrm{pp}$.

McCarville, X., Crossey, L.J., 1996. Post-impact hydrothermal alteration of the Manson impact structure. In: C. Koeberl and R.R. Anderson (Editors), The Manson Impact Structure: Anatomy of an Impact Crater. Geol. Soc. Am. Spec. Pap. 301, 347-376.

Muir, T.L., 1984. The Sudbury Structure: considerations and models for an endogenic origin. In: E.G. Pye, A.J. Naldrett and P.E. Giblin (Editors), The Geology and Ore Deposits of the Sudbury Structure. Ont. Geol. Surv., Spec. Vol. 1, 449489.

Muir, T.L., Peredery, W.V., 1984. The Onaping Formation. In: E.G. Pye, A.J. Naldrett, P.E. Giblin, (Editors), The Geology and Ore Deposits of the Sudbury Structure. Ont. Geol. Surv., Spec. Vol. 1, 139-210.

Müller-Mohr, V., 1992. Gangbreccien der Sudbury-Struktur; Geologie, Petrographie und Geochemie der Sudbury-Breccie, Ontario, Canada. Unpubl. Ph.D. Thesis, University of Münster, $139 \mathrm{pp}$.

Murtaugh, J.G., 1975. Geology of the Manicouagan Cryptoexplosion Structure. Ph.D. Thesis, Ohio State University, Columbus.

Murtaugh, J.G., 1976. Manicouagan Impact Structure. Québec Ministère des Richesses naturelles, DPV-432, $180 \mathrm{pp}$.

Norris, A.W., Sanford, B.V., 1968. Paleozoic and Mesozoic Geology of the Hudson Bay Lowlands. Geol. Surv. Can., Pap. 68-53.

Ontario Geological Survey, 1992. Chart A - Archean Tectonic Assemblages, Plutonic Suites and Events in Ontario. Ontario Geol. Survey, Map 2579.

Peredery, W.V., Morrison, G.G., 1984. Discussion of the origin of the Sudbury Structure. In: E.G. Pye, A.J. Naldrett and P.E. Giblin (Editors), The Geology and Ore Deposits of the Sudbury Structure. Ont. Geol. Surv. 1, 491-511.

Pohl, J., Stöffler, D., Gall, H., Ernstson, K., 1977. The Ries impact crater. In: D.J. Roddy, R.O. Pepin, R.B. Merrill (Editors), Impact and Explosion Cratering. Pergamon Press, New York, pp. 343-404.

Preuss, E., Schmidt-Kaler, H. (Editors), 1969. Das Ries. Geologie, Geophysik und Genese eines Kraters. Geol. Bavarica, 61. $478 \mathrm{pp}$.

Redeker, H.-J., Stöffler, D., 1988. The allochthonous polymictic breccia layer of the Haughton impact crater, Devon Island, Canada. Meteoritics 23, 185-196.

Reimold, W.U., 1991. The geochemistry of pseudotachylites from the Vredefort dome, South Africa. Neues Jahrb. Mineral., Abh. 162, 151-184.

Reimold, W.U., 1995. Pseudotachylite in impact structures generation by friction melting and shock brecciation? A review and discussion. Earth-Sci. Rev. 39, 247-265.

Reimold, W.U., Colliston, W.P., 1994. Pseudotachylites of the Vredefort Dome and the surrounding Witwatersrand basin, South Africa. In: B.O. Dressler, R.A.F. Grieve and V.L. Sharpton (Editors), Large Meteorite Impacts and Planetary Evolution. Geol. Soc. Am., Spec. Pap. 293, 177-196.

Reimold, W.U., Colliston, W.P., Wallach, T., 1992. Comment on
'Nature, provenance and distribution of coesite and stishovite in the Vredefort structure' by J.E.J. Martini. Earth Planet. Sci. Lett. 112, 213-217.

Rondot, J., 1971. Impactite of the Charlevoix structure, Quebec, Canada. J. Geophys. Res. 76, 5414-5423.

Rondot, J., 1995. Les impacts météoritiques à l'example de ceux du Québec. Publications MNH, 157 pp.

Sage, R., 1978. Diatremes and shock features in Precambrian rocks of the Slate Islands, northeastern Lake Superior. Geol. Soc. Am. Bull. 89, 1529-1540.

Sage, R., 1991. Precambrian geology, Slate Islands. Ont. Geol. Surv., Rep. 264, 111 pp.

Shand, S.J., 1916. The pseudotachylite of Parijs (Orange Free State). Q. J. Geol. Soc. London 72, 121-140.

Sharpton, V.L., Dressler, B.O., 1996. The Slate Islands impact structure: structural interpretation and age constraints (Abstr.). Lunar Planet. Sci. Conf. 27, 1177-1178.

Sharpton, V.L., Burke, K., Camargo-Zanogera, A., Hall, S.A., Lee, D.S., Marín, L.E., Suarez-Reynoso, G., Quezada-Muñeton, J.M., Spudis, P.D., Urrutia-Fucugauchi, J., 1993. Chicxulub multi-ring impact basin: size and other characteristics derived from gravity analysis. Science 26I, 1564-1567.

Sharpton, V.L., Dressler, B.O., Herrick, R.R., Schnieders, B., Scott, J., 1996a. New constraints on the Slate Islands impact structure, Ontario, Canada. Geology 24, 851-854.

Sharpton, V.L., Marín, L.E., Carney, J.L., Lee, S., Ryder, G., Schuraytz, B.C.. Sikora, P., Spudis, P.D., 1996b. A model of the Chicxulub impact basin based on evaluation of geophysical data, well logs and drill core samples. In: G. Ryder, D. Fastovsky, S. Gartner (Editors), The Cretaceous-Tertiary Event and Other Catastrophies in Earth History. Geol. Soc. Am., Spec. Pap. 307, 55-74.

Sibson, R.H., 1975. Generation of pseudotachylyte by ancient seismic faulting. Geophys. J. R. Astron. Soc. 43, 775-794.

Speers, E.C., 1957. The age relationship and origin of common Sudbury Breccia. J. Geol. 65, 497-514.

Spray, J.G., 1995. Pseudotachylite controversy: fact or friction? Geology 23, 1119-1122.

Spray, J.G., Thompson, L.M., 1995. Friction melt distribution in a multi-ring impact basin. Nature 373, 130-132.

Spudis, P., 1993. The Geology of Multi-Ring Impact Basins. Cambridge University Press, Cambridge, 263 pp.

Stöffler, D., 1971a. Coesite and stishovite in shocked crystalline rocks. J. Geophys. Res. 76, 5474-5488.

Stöffler, D., 1971b. Progressive metamorphism and classification of shocked and brecciated crystalline rocks in impact craters. J. Geophys. Res. 76, 5541-5551.

Stöffler, D., 1974. Deformation and transformation of rock-forming minerals by natural and experimental shock processes, II. Physical properties of shocked minerals. Fortschr. Mineral. 51, 256-289.

Stöffler, D., 1977. Research drilling Nördlingen 1973: polymict breccias, crater basement, and cratering model of the Ries impact structure. Geol. Bavarica 75, 443-458.

Stöffler, D., 1984. Glasses formed by hypervelocity impact. J. Non-Cryst. Solids 67, 465-502.

Stöffler, D., Langenhorst, F., 1994. Shock metamorphism of 
quartz in nature and experiment, 1. Basic observation and theory. Meteoritics 29, 155-181.

Stöffler, D., Bischoff, L., Oskierski, W., Wietz, B., 1988. Structural deformation, breccia formation, and shock metamorphism in the basement of complex impact craters: Implications for the cratering process. In: A. Boden, K.G. Erikson (Editors), Deep Drilling in Crystalline Bedrock, 1. Springer. Berlin. pp. 277-297.

Swanson, M.T., 1992. Fault structure. wear mechanism and rupture processes in pseudotachylyte generation. Tectonophysics 204, 223-242.

Therriault, A.M., Reid, A.M., Reimold, W.U., 1993. Original size of the Vredefort Structure. South Africa (Abstr.). Lunar Planet. Sci. Conf. 24. 1419-1420.
Therriault, A.M., Grieve, R.A.F., Reimold, W.U.. 1995. How big is Vredefort? In: Abstracts 58th Annual Meeting Meteoritical Society. Meteoritics 30, 586-587.

Thompson, L.M., Spray, J.G., 1994. Pseudotachylitic rock distribution and genesis within the Sudbury impact structure. In: B.O. Dressler, R.A.F. Grieve, V.L. Sharpton (Editors). Large Meteorite Impacts and Planetary Evolution. Geol. Soc. Am., Spec. Pap. 293, 275-287.

Wenk, H.R. 1978. Are pseudotachylites products of fracture or fusion?. Geology 6, 507-511.

Wiest, B., 1987. Diskordante Gangbreccien und strukturelle Merkmale im Untergrund komplexer Impaktstrukturen und ihre Bedeutung für die Kraterbildungsprozesse. Unpubl. Ph.D. thesis. University of Münster, $167 \mathrm{pp}$. 

Publication information

Tectonophysics (ISSN 0040-1951). For 1997 volumes 265-278 are scheduled for publication. Subscription prices are available upon request from the publisher. Subscriptions are accepted on a prepaid basis only and are entered on a calendar year basis. Issues are sent by surface mail except to the following countries where air delivery via SAL is ensured: Argentina, Australia, Brazil, Canada, Hong Kong, India, Israel, Japan, Malaysia, Mexico, New Zealand, Pakistan, PR China, Singapore, South Africa, South Korea, Taiwan, Thailand, USA. For all other countries airmail rates are available upon request. Claims for missing issues must be made within six months of our publication (mailing) date. For orders, claims, product enquiries (no manuscript enquiries) please contact the Customer Support Department at the Regional Sales Office nearest to you:

New York, Elsevier Science, P.O. Box 945, New York, NY 10159-0945, USA. Tel: (+1) 212-633-3730. [Toll Free number for North American customers: 1-888-4ES-INFO (437-4636)], Fax: (+1) 212-633-3680, E-mail: usinto-f@elsevier.com

Amsterdam, Elsevier Science, P.O. Box 211, 1000 AE Amsterdam, The Netherlands. Tel: (+31) 20-485-3757, Fax: (+31) 20-485-3432, E-mail: nlinfo-t@elsevier.nl

Tokyo, Elsevier Science, 9-15, Higashi-Azabu 1-chome, Minato-ku, Tokyo 106, Japan. Tel: (+81) 3-5561-5033, Fax: (+81) 3-5561-5047, E-mail: kyf04035@ nittyserve.or.jp

Singapore, Elsevier Science, No. 1 Temasek Avenue, \#17-01 Millenia Tower, Singapore 039192. Tel: (+65) 434-3727, Fax: (+65) 337-2230, E-mail: asiainfo@elsevier.com.sg

US mailing notice - Tectonophysics (ISSN 0040-1951) is published bi-weekly by Elsevier Science B.V. (Molenwert 1, Postbus 211, 1000 AE Amsterdam). Annual subscription price in the USA US\$ 2505 (US\$ price valid in North, Central and South America only), including air speed delivery. Periodicals postage paid at Jamaica, NY 11431.

USA POSTMASTERS: Send address changes to Tectonophysics, Publications Expediting, Inc., 200 Meacham Avenue, Elmont, NY 11003. Airfreight and mailing in the USA by Publications Expediting.

Advertising information

Advertising orders and enquiries may be sent to: Elsevier Science, Advertising Department, The Boulevard, Langford Lane, Kidlington, Oxford, Ox5 1GB. UK, tel.: (+44) (0) 1865 843565, fax: (+44) (0) 1865 843952. In the USA and Canada: Weston Media Associates, attn. Dan Lipner, P.O. Box 1110 Greens Farms, CT 06436-1110, USA, tel.: (203) 2612500 , tax: (203) 261 0101. In Japan: Elsevier Science Japan, Marketing Services, 1-9-15 Higashi-Azabu, Minato-ku, Tokyo 106, Japan, tel.: (+81) 355615033 , fax: (+81) 355615047

\section{NOTE TO CONTRIBUTORS}

A detailed Guide for Authors is available on request. Please pay attention to the following notes:

Language

The official language of the journal is English.

Preparation of the text

(a) The manuscript should preferably be prepared on a word processor and printed with double spacing and wide margins and include an abstract of not more than 500 words.

(b) Authors should use IUGS terminology. The use of S.I. units is also recommended.

(c) The title page should include the name(s) of the author(s), their affiliations, fax and e-mail numbers. In case of more than one author, please indicate to whom the correspondence should be addressed.

References

(a) References in the text consist of the surname of the author(s), tollowed by the year of publication in parentheses. All references cited in the text should be given in the reference list and vice versa.

(b) The reference list should be in alphabetical order

Tables

Tables should be compiled on separate sheets and should be numbered according to their sequence in the text. Tables can also be sent as glossy prints to avoid errors in typesetting.

Illustrations

(a) Illustrations should be submitted in triplicate. Please note that upon submission of a manuscript three sets of all photographic material printed sharply on glossy paper or as high-definition laser prints must be provided to enable meaningful review. Photocopies and other low-quality prints wilt not be accepted for review.

(b) Colour figures can be accepted providing the reproduction costs are met by the author. Please consult the publisher for further information

Page proots

One set of page proots will be sent to the corresponding author, to be checked for typesetting/editing. The author is not expected to make changes or corrections that constitute departures from the article in its accepted form. To avoid postal delay, authors are requested to return corrections to the desk-editor, Mr. Herman E. Engelen, by FAX $(+31.20 .4852459$ ) or e-mail (h.engelen elsevier.nl), preferably within 3 days.

Reprints

Fifty reprints of each article published are supplied free of charge. Additional reprints can be ordered on a reprint order form, which will be sent to the corresponding author upon acceptance of the article.

Submission of manuscripts

Three copies should be submitted to: Editorial Office Tectonophysics, P.O. Box 1930, 1000 BX Amsterdam, The Netherlands

Submission of an article is understood to imply that the article is original and unpublished and is not being considered for publication elsewhere.

Upon acceptance of an article by the journal, the author(s) will be asked to transfer the copyright of the article to the publisher. This transfer will ensure the widest possible dissemination of information under the U.S. Copyright Law.

The indication of $a$ fax and e-mail number on submission of the manuscript could assist in speeding communications. The fax number for the Amsterdam office is $+31-20-4852696$

Authors in Japan, please note: Upon request. Elsevier Science Japan will provide authors with a list of people who can check and improve the English of their paper (before submission). Please contact our Tokyo office: Elsevier Science Japan, 1-9-15 Higashi-Azabu, Minato-ku, Tokyo 106: Tel. (+81) $355615032 ; \mathrm{Fax}(+81) 355615045$

THERE ARE NO PAGE CHARGES

Submission of electronic text

In order to publish the paper as quickly as possible after acceptance authors are encouraged to submit the final text also on a $3.5^{\prime \prime}$ or $5.25^{\prime \prime}$ diskette. Essential is that the name and version of the wordprocessing program, type of computer on which the text was prepared, and format of the text files are clearly indicated. Authors are requested to ensure that apart from any such small last-minute corrections, the disk version corresponds exactly to the hardcopy.

If available, electronic files of the figures should also be included on a separate floppy disk. 


\section{Physics and Evolution of the Earth's Interior}

\section{Series now complete!}

\section{Constlution of the Earth's Interior}

Edited by J. Leliwa

-Kopystynskl and

R. Teisseyre

Physics and Evolution of the Earth's Interior Volume 1

1984 xii + 368 pages

Dfl. 267.00 (US $\$ 152.50$ )

ISBN 0.444-99646-X

Seismic Wave Propagation In the Earth

\section{By A. Hanyga}

Physics and Evolution of the Earth's Interior Volume 2

$1985 \times v i+478$ pages

Dfl. 318.00 (US $\$ 181.75$ )

ISBN 0-444-99611-7

\section{Continuum Theories in} Solid Earth Physics

\section{Edited by R. Teisseyre}

Physics and Evolution of the Earth's Interior Volume 3 1986 xiv + 566 pages Dfl. 376.00 (US $\$ 214.75$ ) ISBN 0.444-99569-2

\section{Gravity and Low} - Frequency Geodynamics

\section{Edited by $\mathbf{R}$. Telsseyre}

Physics and Evolution of the Earth's Interior Volume 4 1989 xii +478 pages Dil. 313.00 (US $\$ 178.75$ ) ISBN 0-444-98908-0
This six-volume series deals with the most Important problems of solid Earth physles and presents the most general theories describing contemporary dynamical processes and the Earth's evolution.

Six-Volume Set

Dfl. 1350.00 (US $\$ 771.00$ )

ISBN 0-444-81750-6

\section{Evolution of the Earth and} Other Planetary Bodles

Edited by R. Teisseyre, J. Leliwa-KopystynskI and B. Lang

Physics and Evolution of the Earth's Interior Volume 5

"This volume is a competently constructed up-to-date and detailed summary of planetary evolution. It is for the planetary scientist above other fields; in this category, the book deserves a wide readership simply for its breadth of coverage. Researchers in other fields will also find this a book worth dipping into, and whole lecture courses could be based around its contents. It appears that the initial wish to discuss planetary evolution across the solar system has resulted in an intelligent, advanced level treatise that will become widely referenced itself."

Earth-Science Reviews

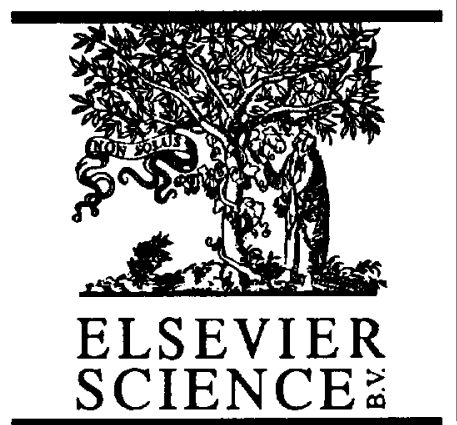

1992 xii + 584 pages Dfl. 370.00 (US $\$ 211.50$ ) ISBN 0-444-98833-5

Dynamics of the Earth's Evolution

Edited by R. Telsseyre,

L. Czechowskl and J. Leliwa-Kopystynsk|

Physics and Evolution of the Earth's Interior Volume 6

This sixth volume in the monograph series Physics and Evolution of the Earth's interior presents the problems of the mature evolution of the Earth's interior. It provides comprehensive coverage of the present state of the mantle convection theory. The relations between paleomagnetism, plate tectonics and mantle convection theory are discussed. A more general view of the evolution based on the thermodynamics of irreversible processes is also given.

1993480 pages

Dfl. 350.00 (US $\$ 200.00$ ) ISBN 0-444-98662-6

ELSEVIER SCIENCE B.V. P.O. Box 1930

1000 BX Amsterdam

The Netherlands

P.O. Box 945

Madison Square Station New York, NY 10160-0757

The Dutch Guilder (Dfl.) prices quoted apply worldwide. US \$ prices quoted may be subject to exchange rate fluctuations. Customers in the European Community should add the appropriate VAT rate applicable in their country to the price. 